9-1997

\title{
Feminists and neo-Malthusians: Past and present alliances
}

\author{
Dennis Hodgson \\ Fairfield University, hodgson@fairfield.edu
}

Susan C. Watkins

Follow this and additional works at: https://digitalcommons.fairfield.edu/sociologyandanthropologyfacultypubs

Archived with permission from the copyright holder.

Copyright 1997 Wiley and Population Council.

Link to the journal homepage: (http://wileyonlinelibrary.com/journal/padr)

\section{Peer Reviewed}

\section{Repository Citation}

Hodgson, Dennis and Watkins, Susan C., "Feminists and neo-Malthusians: Past and present alliances" (1997). Sociology \& Anthropology Faculty Publications. 34.

https://digitalcommons.fairfield.edu/sociologyandanthropology-facultypubs/34

\section{Published Citation}

Hodgson, Dennis; Watkins, Susan. "Feminists and neo-Malthusians: Past and present alliances," Population and Development Review 23, no. 3 (September 1997): 469-523.

This item has been accepted for inclusion in DigitalCommons@Fairfield by an authorized administrator of DigitalCommons@Fairfield. It is brought to you by DigitalCommons@Fairfield with permission from the rightsholder(s) and is protected by copyright and/or related rights. You are free to use this item in any way that is permitted by the copyright and related rights legislation that applies to your use. For other uses, you need to obtain permission from the rights-holder(s) directly, unless additional rights are indicated by a Creative Commons license in the record and/or on the work itself. For more information, please contact digitalcommons@fairfield.edu. 


\title{
Feminists and Neo-Malthusians: Past and Present Alliances
}

\author{
DenNis Hodgson \\ Susan CotTs WatkIns
}

The Program of Action (United Nations 1994) adopted at the International Conference on Population and Development in Cairo is intended to establish international population policy for the next two decades. It is an unusual population policy document. The phrase "population problem" never occurs in its pages; more significantly, no demographic factor is identified as the principal cause of any problem, and few demographic changes are sought. The Program assigns (in Principle 4) an explicit feminist agenda to population programs:

\begin{abstract}
Advancing gender equality and equity and the empowerment of women, and the elimination of all kinds of violence against women, and ensuring women's ability to control their own fertility, are cornerstones of population and development-related programmes.
\end{abstract}

The purpose of population programs is to promote reproductive health, defined (in paragraph 7.2) as ensuring women "the capability to reproduce and the freedom to decide if, when and how often to do so." A family planning program is an appropriate part of such a program (7.12) if it employs no "form of coercion," uses no "incentives and disincentives," and imposes no demographic "targets" or "quotas" on providers. The document melds feminist and human rights rhetoric into a programmatic position that bans explicit attempts to influence reproductive behavior.

Yet a neo-Malthusian subtext still runs through much of the Program and occasionally breaks through to the surface of the document (3.14): 
Slower population growth has in many countries bought more time to adjust to future population increases. This has increased those countries' ability to attack poverty, protect and repair the environment, and build the base for future sustainable development. Even the difference of a single decade in the transition to stabilization levels of fertility can have a considerable positive impact on quality of life.

The presumptions of a neo-Malthusian movement that for nearly half a century has sought to make fertility reduction an important objective of international policy are invariably echoed: low rates of population growth are beneficial; more rapid fertility declines are better than slower declines; and population stabilization is an ultimate goal.

Despite this mild neo-Malthusianism, in volume the feminists' commitment to the rights of the individual woman is granted much more significance than the neo-Malthusians' emphasis on the prerogatives of the group. The Program offers a rationale for this bias by asserting (3.16) that "eliminating social, cultural, political and economic discrimination against women" is a "prerequisite" for "achieving balance between population and available resources." Protecting the individual rights of women is thus presented as an indispensable means for achieving aggregate neo-Malthusian ends.

Cairo distinguished itself from earlier population conferences by having its population strategies depend so extensively upon attaining feminist aims. The Bucharest document (United Nations 1974) called for the equal participation of women in the economic, social, and political life of their countries, and specifically sought to increase women's education. The Mexico City document (United Nations 1984) noted that improving the status of women was an important goal in and of itself, and that it would also lower family size. The Cairo document went a step further and contended that unless women's status was improved, lasting population stabilization was unlikely. In the Program of Action the agenda of the neoMalthusian movement coalesces with that of the feminist reproductive health movement, and both neo-Malthusians and feminists at Cairo spoke in terms of a "common ground." Neo-Malthusians commit themselves to a gender equity strategy for attaining population stabilization, and programmatically agree to supplement family planning activities with reproductive health activities that add several times to program costs. Feminists thereby gain an ally for gender equity campaigns and a commitment to additional funding for women's health programs. They offer, in turn, only lukewarm support for neo-Malthusian goals, and that support is heavily circumscribed with human rights rhetoric regarding choice.

What conditions will make for a lasting alliance between neo-Malthusians and feminists? This question takes us beyond the specific terrain of Cairo and into a historical consideration of neo-Malthusianism and femi- 
nism as social movements with ideologies, strategies, and resources, including money, members, and organizational allies. ${ }^{1}$ Histories of the neoMalthusian movement privilege individuals and organizations, while accounts of Cairo privilege individuals and interest groups (Piotrow 1973; Donaldson 1990; Harkavy 1995; Campbell 1993; McIntosh and Finkle 1995). Our story, in contrast, treats neo-Malthusianism and feminism as social movements, ones aimed at influencing state policy. It privileges ideologies-the set of beliefs that give coherence to the collective activities of a movement (Buechler 1990: 85)-and the way in which ideologies are framed, and reframed, in specific political and social contexts (Goffman 1974; Snow et al. 1986; Mueller 1992). ${ }^{2}$ We examine the extent to which the neo-Malthusian movement and the feminist movement have common goals and their perceptions of mutual benefit. As we shall see, feminists and neo-Malthusians are neither natural allies nor natural opponents. Only occasionally do the immediate goals of these movements merge, and even then one or both parties do not necessarily seek an alliance. ${ }^{3}$

The ideological belief that informs American feminism has been consistent over the past century: an unacceptable inequality exists between women and men. ${ }^{4}$ Despite this degree of unity, the feminist movement has often been divided. The main fault lines have been between liberal feminists who emphasize removing legal barriers to women's equality with men, and radical feminists who insist equality can only be achieved through the establishment of positive rights requiring a profound transformation of economic and social structures (Freedman and Isaacs 1993). Only occasionally have some feminists called for recasting the reproductive role of women as a way of redressing inequality. Margaret Sanger and the early birth controllers were one such group. ${ }^{5}$

We use the term "population control" to refer to movements that have as their goal changing aggregate population characteristics. These include pronatalist, eugenic, and antinatalist movements. Although population control movements may involve coercion, it is a mark of the success of the reproductive rights feminists that control has been redefined to imply coercion, and the terms "population control" and "population controller" are no longer respectable. In this article we focus on the antinatal neo-Malthusian population movement, since our interest is in the "common ground" alliance at Cairo and earlier alliances between neo-Malthusians and feminists. The ideological belief that informs neo-Malthusianism is that excessive population is a major cause of poverty, and that lowering fertility will facilitate prosperity. A continuing tension in the movement has revolved around the question whether voluntary programs that simply provide improved access to contraception are sufficient to prevent potential societal disaster. While it is likely that the majority in the contemporary neo-Malthusian movement believe that such programs are indeed sufficient, at times 
the image of looming catastrophe induced by population growth persuaded some (Davis 1967) that "beyond family planning measures" were needed to reduce fertility, measures that have, at one time or another, included advocacy in the media, targets, incentives and/or disincentives, and outright coercion. Currently, most neo-Malthusians prefer to identify their goal as "population stabilization," not "population control"; in current usage, the latter implies coercion, the former does not. Obviously, exorcising all hint of coercion from neo-Malthusianism greatly enhances its compatibility with feminism.

We confine our examination to the interaction between American feminists and American neo-Malthusians. We recognize the important international component to both social movements, evidenced by international meetings and considerable cooperation among activists from many countries, and we recognize that the Program of Action was fashioned by numerous actors, among whom feminists from Southern countries were prominent. Nonetheless, the ideology and objectives of social movements are still crucially responsive to national conditions. A focus on American feminists and American neo-Malthusians is justified because their relationship has much to do with the present cast of international population policy. ${ }^{6}$ Also, since the implementation of the Cairo agenda must still be funded, and much is expected of the American government, understanding the dynamics of this relationship in the United States provides a special insight into the viability of that policy. Our analysis begins in the early twentieth century and stops with the Cairo conference. This extended time period helps us to uncover long-term changes in movement interactions, and allows us to identify the conditions under which alliances develop and flourish as well as those under which they do not.

Feminists and neo-Malthusians have encountered each other during recurring attempts both have made to shape reproductive behavior by influencing state policy. First we examine early-twentieth-century encounters, when most American feminists were focused on gaining suffrage for women and when American neo-Malthusians had to contend with successful population movements-eugenics, and immigration restriction-that were animated by concerns of population composition rather than fear of overpopulation. We divide the post-World War II era into four periods: 1945-65, 1965-74, 1974-85, and 1985-95. This periodization is based on important events in one or both of the movements and is somewhat arbitrary since there are trends that cross several periods.

The 1945-65 period is characterized by a quiet alliance between a growing number of neo-Malthusians, located primarily in foundations and universities, and a mildly feminist planned parenthood movement. It ends with the adoption of an international neo-Malthusian policy by the US government and the establishment of the National Organization for Wom- 
en (NOW). The period 1965-74 is characterized by a rapid growth in the resources and the global networks of the neo-Malthusian movement. There is a revival of the feminist movement, which had been quiescent since the 1920s, and with it the beginning of feminist critiques of international population programs, many of them from the Left and largely ignored by the population establishment. The 1974-85 period begins with a turning point for neo-Malthusianism, when the international community rejects calls for an all-out fertility control campaign at Bucharest and adopts instead a mild developmentalist position that ensconces birth control firmly within individual-rights rhetoric. Combat with a pro-life movement aroused by the Supreme Court's Roe v. Wade decision in 1973 rallies American feminists around a pro-choice reproductive agenda that becomes a requirement for feminist identity. The last period, 1985-95, sees the further weakening of neo-Malthusian ideology and the skillful elaboration of a feminist population policy and a strategy with which to implement it. ${ }^{7}$

\section{Population movements and feminism:}

\section{Early alliances}

Social movements arise, and succeed or fail, in specific historical contexts. The contrast is stark between the contemporary neo-Malthusian and feminist movements and their predecessors at the beginning of the twentieth century. ${ }^{8}$ Although back then a small neo-Malthusian movement pointed to the link between numerous progeny and poverty, the larger eugenics movement with its interest in shaping population processes to achieve a desirable population composition was far more influential. Among those who wanted greater equality between women and men, a consensus existed that gaining political equality (specifically, suffrage) ought to be the primary goal. A few figures attempted alliances between the women's movement and population movements. Margaret Sanger, for example, forged a birth control movement, led by middle-class women, that was aimed at legalizing access to contraception. She fashioned an ideology that neatly combined feminism, neo-Malthusianism, and eugenics. Rebuffed by suffrage leaders, she eventually formed a sturdy alliance with neo-Malthusians and eugenists.

In 1907, President Theodore Roosevelt decried (p. 550) the "race suicide" of upper-class women, many deeply involved in the suffrage movement, who were avoiding marriage or having small families: "the greatest problem of civilization is to be found in the fact that the well-to-do families tend to die out; there results, in consequence, a tendency to the elimination instead of the survival of the fittest." At the time eugenists worried that the "prudent and thoughtful" ("whose children the race needs") would be the ones to practice birth control, while knowledge of contraception 
was unlikely to affect the fertility of the "reckless" lower classes (Clarke 1896: 357; Popenoe 1917: 6). Such compositional worries fueled both opposition to the legalization of contraception and the immigration restriction movement.

Women in the suffrage movement, the principal women's rights movement at the time, had to respond to charges of race suicide. A majority chose to avoid a direct confrontation with a movement that had a US president as a spokesman. They accepted "the eugenic logic of race suicide theory," but questioned the eugenic efficacy of making women bear unwanted children who "were likely to be neglected and therefore inferior" (Gordon 1990: 141). The suffragists' goal was to convince a substantial majority of male legislators that giving women the vote was wise social policy. In the cultural climate of the early twentieth century, this could best be done by depicting women as strong upholders of traditional values whose presence in the voting booth would lend support for moral renewal. At this time not advancing a reproductive rights agenda was thought to be the wisest feminist tactic. However, new feminist voices, ones that spoke explicitly of the need for women to gain control of their reproductive destinies, made this strategy difficult to sustain.

Emma Goldman, an anarchist, attended the 1900 International NeoMalthusian Conference in Paris and began promoting contraception and "voluntary motherhood" in lectures and in her periodical, Mother Earth (Woloch 1984: 367). She took a socialist neo-Malthusian position, calling on working women as a class to "no longer be a party to the crime of bringing hapless children into the world only to be ground into dust by the wheel of capitalism and to be torn into shreds in trenches and battlefields" (1916: 470). The working class could improve its negotiating position with capitalists by restricting the production of new workers, and they could crimp the expansionist plans of militarist leaders with "birth strikes." Contraception could be used to bring the ruling class to its knees. Margaret Sanger, who did the most of anyone to establish the birth control movement in the United States, initially adopted much of Goldman's orientation. A socialist and member of the International Workers of the World (IWW), Sanger founded The Woman Rebel in 1914 to bring knowledge of contraception to the masses. Sanger was also a member of "the new intellectuals" among American socialists who argued that "sex be made a major issue of revolutionary politics and women's liberation" (Buhle 1983: 259).

Both Goldman and Sanger purposely broke laws and attracted crowds and enormous attention for "birth control," the term coined in 1914 to represent Sanger's campaign (Chesler 1992: 97). Contraception and small families now were linked to feminism, radicalism, and sexual liberation. Despite the evidence that the birth control movement was capable of mobilizing women, suffragists remained ambivalent about it. The interest sur- 
rounding birth control reflected a new facet of feminism, more radical and sexual, that attracted a younger and more nonconformist constituency for the cause. This new sexual agenda, however, antagonized a public just coming to accept the suffrage rationale that women's rights advocates had carefully constructed over decades. When Sanger sought allies in the women's movement by asking 50 prominent women in 1915 to state publicly that they believed in and practiced birth control, she was turned down and told to "wait until we get the vote" (Gordon 1990: 233-236). When she asked Carrie Chapman Catt for use of her name as sponsor for the American Birth Control League, Catt responded that while "I am no enemy of you and yours. . . . Your reform is too narrow to appeal to me, and too sordid." If feminists in the 1910 s had a "common ground" position, it was that suffrage was their primary objective. The struggle for women to control their reproductive lives did not provide a foundation for feminist unity as it does today.

The birth control movement underwent rapid and consequential change from 1915 to 1920 . Sanger started the period unequivocally on the Left: taking part in IWW strikes and publishing in The Woman Rebel articles defending assassination and denouncing marriage. In 1914 she fled the country to escape prosecution for breaking the Comstock laws censoring literature deemed obscene. Yet on her return she adopted a rhetoric that was more standard neo-Malthusian and eugenic than anticapitalist: namely, more birth control would lead to less poverty and fewer defective offspring (Woloch 1984: 373). She even argued that only medical professionals ought to distribute contraceptives, a less radical position than that taken by Mary Ware Dennett, a middle-class activist whose National Birth Control League was fighting for the unfettered distribution of contraceptive information. We believe that this change in Sanger's stance was due, at least in part, to her recognition that she needed new allies if she was to achieve her aim of legalizing contraception. In 1917 she broke her ties with the Left. The Bolshevik Revolution had provoked worries that a communist upheaval threatened the United States, and thus an alliance with the Left was not advantageous. To dampen suffragists' concerns that birth control was "too sordid," Sanger sought to remove the explosive sexual component from birth control by treating it as a medical issue and placing the distribution of contraceptives in the hands of physicians. Yet even after the passage of the 19th Amendment granting women suffrage in 1920, Sanger could not get women's organizations to support her movement. Birth control remained too controversial and too potentially divisive for the National Woman's Party, the National League of Women Voters, and even the Child Welfare and Social Hygiene Committees of the League of Women Voters to support. ${ }^{9}$

Sanger, a pragmatic activist (McCann 1994), thus turned for allies both to the tiny neo-Malthusian movement and to the influential eugenics movement. She asked Edward Alsworth Ross to write (1920) neo-Malthusian 
defenses of birth control in her new journal, Birth Control Review, and recruited Lothrop Stoddard, whose The Rising Tide of Color Against White World Supremacy (1920) depicted a slowly increasing white race being overwhelmed by more rapidly increasing "colored" races, to serve on the board of the American Birth Control League along with the eugenist C. C. Little. To the lower social strata who suffered from poverty and ill health, she issued neo-Malthusian missives on the improved health and economic wellbeing that would come to those with small families. To the elite who harbored eugenic fears, she argued that bettering the race required improving the access of the less fit to contraception.

By 1920 Sanger had forged a birth control movement, led by middleclass women, aimed at procuring for doctors the legal right to distribute contraceptives to women. Birth control remained a feminist endeavor (Sanger 1922: 11): "Birth control is the means by which woman attains basic freedom." It is also a neo-Malthusian enterprise (1922: 204-205): "a science which teaches that poverty and social evils can be greatly reduced by encouraging people to have small families." Additionally, birth control is the foundation for all eugenic programs (1919: 12): "Eugenics without Birth Control seems to us a house built upon the sands." In practical terms, the alliance with eugenists was probably of greater utility for Sanger's birth control movement than her alliance with the neo-Malthusians.

The alliance with the eugenists was made possible by a change in the eugenists' assessment of birth control during the 1920s. It had become so prevalent among the "higher quality stock" that they no longer feared its legalization. A new interpretation of fertility trends contributed to this reversal. A general downward trend in the fertility of all class and ethnic groups had become evident, and the inverse relationship between class and fertility that panicked the turn-of-the-century eugenist now appeared to be temporary. This same downward trend in US fertility, however, lessened the salience of neo-Malthusian rationales for birth control. In 1925 Louis Dublin and Alfred Lotka (pp. 328-329) developed "intrinsic" vital rates that controlled for the age structure's influence on crude rates, and dramatically announced that the average American woman in 1920 was having only half a child more than was needed to maintain a stationary population. Dublin was quick (1926) to use intrinsic measures to generate a sense of crisis, even identifying excessive birth control as a national problem. He predicted (1932: 233) the onset of actual depopulation "during the next five or ten years," attacked Sanger by name, and argued that birth control was "a one-sided movement" that had convinced too many people to exercise "much more birth control than was either good for them or for the community at large." When a significant pronatalist movement developed and fears of domestic depopulation, not overpopulation, predominated, neo-Malthusianism lost much of its utility for Sanger. 
During this period, and through much of the 1930s, it even became problematic to decry overpopulation abroad. The popularity of Ross's Standing Room Only? (1927) reflected a genuine interest in the geopolitical ramifications for the West of the differential rates of population growth then evident among nations. But in 1929 Warren Thompson, studying these trends, produced (1929a) the first expression of demographic transition theory. Countries industrializing and urbanizing, he theorized, would experience a Western sequence of demographic changes: a movement from an initial state of low population growth with high birth and death rates, to one of rapid population growth with differentially declining vital rates, to one of low growth with low vital rates. This theory became politically suspect because of the particular historical context, specifically the policy implications that Thompson drew from applying it to Japanese population dynamics. He concluded (1929b: 43) that Japan, in the midst of its rapid population growth, had only one alternative: "to expand by the acquisition of more territory." This would increase the Japanese supply of natural resources needed for rapid industrialization while providing relatively empty areas capable of absorbing a portion of Japan's increasing population. Thompson actually called on European nations to voluntarily cede to Japan "lands not used and not needed by them" in Southeast Asia so that war could be avoided (1930: 366). Such "scientific" support for the frequently voiced Japanese contention that their commercial and military expansion in Asia was necessitated by population pressure endeared this theory to few Western policymakers, and it was largely ignored, even by academics, for the next decade.

During an era when Lebensraum arguments for imperialism abounded, emphasizing the reality of overpopulation became politically dangerous. ${ }^{10}$ Sanger entered more fully into the eugenists' camp. Although she saw the eugenists as valuable allies and shared their ideology to a considerable extent, she parted with them on some issues. She never approved of the state coercing women to bear children, for example. She did, however, approve of the state limiting the reproduction of the unfit, for instance by offering "a bonus or a yearly pension to all obviously unfit parents who allow themselves to be sterilized by a harmless and scientific means" (1926: 299). She held that certain conditions "demand the exercise of birth control": having a heritable disease; having had a defective child; and even being poor (1925: 31-32). Such positions were enough to earn Sanger the support of most eugenists, and the American Eugenics Society formally endorsed Sanger's birth control campaign in 1933 (Chesler 1992: 343).

The alliance that Margaret Sanger fashioned with the eugenists was a sturdy one. Both movements had the goal of increasing the access of the lower classes to birth control. Both movements perceived mutual benefit in an alliance. Eugenists thought themselves lucky to have an ally who 
could market birth control as a way to better health and wellbeing, not as a preventive for race degradation, and Sanger much appreciated the prestige and scientific credentials that eugenists brought to her cause of convincing the public of the need to legalize access to birth control. Finally, Sanger shared with the eugenists a conviction that societal benefit would come from the "less fit" having fewer children.

Our historical examination leads us to believe that shared goals, perceived mutual benefit in an affiliation, and compatible ideologies are preconditions for a lasting alliance between social movements. This particular one lasted through the 1930s, and in fact became so strong that some saw (Fairchild 1940) the two movements merging: "One of the outstanding features of the present conference [1940 Annual Meeting of the Birth Control Federation] is the practically universal acceptance of the fact that these two great movements [eugenics and birth control] have now come to such a thorough understanding and have drawn so close together as to be almost indistinguishable." During that decade Sanger withdrew from leadership positions in the birth control movement. By 1939 the Birth Control Federation of America, formed by the merger of Sanger's Clinical Research Bureau and the American Birth Control League, was led by male professionals who were calling for more babies from the fit (Chesler 1992: 392393; McCann 1994: 134).

Although the alliance between the birth control movement and eugenists remained strong through the 1930s, American eugenists suffered as public opinion began turning against a movement so closely associated with Nazi Germany. Had Sanger been driven only by the goals of her birth control movement and related tactical considerations, she might have publicly distanced herself from the eugenists, a move she never made. Apparently alliances can weaken as well as invigorate a movement. Feminism as a distinct movement fared even more poorly than did eugenics during the 1930s, and nearly disappeared from the American scene (Buechler 1990: 2 ). Those within the birth control movement whose primary goal was to further gender equity were unable to prevent the systematic distancing of the movement from its feminist roots, symbolized by its rechristening in 1942 as the "Planned Parenthood Movement," a term that centered attention on families and children and not on women and sex (Gordon 1990: 340).

Neo-Malthusianism and feminism, 1945-65:

A second alliance

Changes wrought by World War II and the Nazi and Fascist regimes of Europe significantly altered American population movements: eugenics lost its public acceptability, and an unexpected postwar baby boom ended the fears of domestic depopulation that had produced the pronatalist move- 
ment of the late 1920s and 1930s. At midcentury few considered domestic demographic trends to be problematic. However, when certain American students of population, primarily located at Princeton University, turned to what were then called the underdeveloped countries, they saw much cause for alarm. With inexpensive public health measures dramatically reducing mortality, their populations were described as exploding. This growth threatened to thwart industrialization plans. Retrograde or stagnant economic conditions were thought to be a breeding ground for communism. American population specialists successfully solicited the support of John D. Rockefeller 3rd and Ford Foundation officers, and began a multi-decade effort "to create a transnational epistemic community around the principles of population growth as an obstacle to economic development and family planning programs as a feasible solution" (Crane 1993: 358). This coalition of concerned academics and foundation leaders established in elite US universities a policy-oriented demographic discipline focused on third world population problems that provided the intellectual backbone for an influential neo-Malthusian movement in the United States, one that quickly gained international adherents.

Initially much attention focused on the large population of newly independent India. When it was viewed in conjunction with India's limited arable land, the specter of more people than could be adequately fed appeared to be a near-term possibility. Controlling population size seemed essential to averting famine and malnutrition. Since similar population/ resource relationships were common in Asia, the population crisis was initially framed as a peculiarly "Asiatic problem." ${ }^{\text {"1 }}$ Would food and natural resource supplies be adequate to feed, clothe, and shelter large and dense populations that were growing rapidly? Would there be sufficient resources for such populations to urbanize and industrialize even if their basic needs could be met?

At first these academics were pessimistic about the possibility of stimulating fertility decline by bringing contraception directly to peasants (Hodgson 1983). As Thompson had in 1929, they encapsulated the demographic history of Western populations into demographic transition theory, in which fertility decline was identified as a consequence of industrialization and urbanization. ${ }^{12}$ Now, however, when examining the situation of postwar underdeveloped regions, they concluded that population growth trends were hindering efforts to transform traditional agrarian economies into modern industrial ones. This posed a demographic conundrum: the modernization process was being stymied by a demographic stumbling block that itself, according to their understanding of demographic/economic interactions, could only be humanely eliminated through rapid modernization. Although they had no feasible, non-catastrophic resolution to this conundrum, they hesitated to recommend family planning programs since 
they assumed that peasants would be little motivated to practice contraception. This iteration of transition theory, arising in a different context, one where third world population growth was seen as threatening the interests of an embattled "free world," elicited greater interest among policymakers and academics than had Thompson's 1929 version.

Birth control advocates were considerably less gloomy than academics about prospects for family planning in less developed countries. In 1946 Margaret Sanger came out of retirement in an effort to internationalize the planned parenthood movement (Chesler 1992: 407-463), attending a family planning meeting in Stockholm, Sweden where a call for an international planned parenthood organization was initiated. In 1948 she organized the International Congress on Population and World Resources in Relation to the Family, in Cheltenham, England, attended by representatives from 17 countries and from the newly formed United Nations. She was appointed chair of the committee that formally established the International Planned Parenthood Federation (IPPF) at the Second International Conference in Bombay, India, in 1952. Sanger co-directed the IPPF until her retirement in 1959, and imprinted it with her feminist belief that birth control was essential for women's freedom. The IPPF during this period, however, was not well funded, and its ability to aid in the establishment of family planning clinics in less developed countries was limited. ${ }^{13}$

When significant funds for a global fertility control effort began to flow from foundations in 1952, they were largely funneled to the population specialists, not the IPPF birth controllers (Piotrow 1973: 15-18). John D. Rockefeller 3rd convened a conference in 1952 under the auspices of the US National Academy of Sciences to examine the growing imbalance in Asia's vital rates (Notestein 1982: 676-677; Bachrach and Bergman 1973: 44-46). Five months later the Population Council was established with Rockefeller as its president. During that same year the Ford Foundation began funding population activities (Caldwell and Caldwell 1986: 32). By 1961 these funds had spawned seven new university-based demography programs aimed at training specialists on the population problems of developing countries (Stycos 1967). Research on a contraceptive pill increased optimism that focused interventions were possible. By the mid-1950s most population specialists were advocating efforts to bring birth control "directly" to peasants. Pilot family planning projects were begun in India and elsewhere.

Such activities were considered controversial during the 1950s. At the United Nations World Population Conference held in Rome in 1954, a coalition of Catholics and communists prevented consideration of any action agenda. ${ }^{14}$ President Dwight Eisenhower feared Roman Catholic opposition and refused to support international fertility control: "When I was President, I opposed the use of Federal funds to provide birth control information to countries we were aiding because I felt this would violate the deep- 
est convictions of a large group of taxpayers" (1963: 27). Yet voluntary family planning programs were considered by influential opinion makers to be excellent philosophical complements to the gradualist development strategies being promoted by US foreign aid programs; and powerfully positioned neo-Malthusians began making concerted efforts during the late 1950s to gain government support for the movement. ${ }^{15}$

Meanwhile alliances were made between planned parenthood proponents and population specialists. Planned parenthood representatives and members of the Population Council met in 1955, 1956, and 1957 "to develop and define general principles for promoting birth control overseas" (Piotrow 1973: 14). Population Council and IPPF representatives discussed contraceptive technology in 1957, and planned small field tests of the birth control pill in Los Angeles and in Puerto Rico (Chesler 1992: 443-444). By the early 1960s they had developed a standard choreography for encouraging third world governments to adopt national family planning programs. First, foundations would grant fellowship support for nationals to study demography at various US population centers, where they would absorb a crisis orientation toward population growth. Next, a "KAP" survey of the local population's knowledge, attitudes, and practice of contraception would be undertaken. The survey results would be used to document the existence of a "ready market" for birth control, to convince any skeptical national leaders and bureaucrats that family planning was possible, ${ }^{16}$ and to prepare the way for the national planned parenthood association, with financial and technical assistance from IPPF, to establish a limited number of clinics within the country. Successfully-operating private clinics would be used to demonstrate the feasibility of establishing a national family planning program.

Initially, tensions existed in this alliance between population specialists and planned parenthood proponents. During this period planned parenthood proponents were even more action-oriented than the population specialists. William Vogt, president of the Planned Parenthood Federation of America, wrote one of the earliest and most influential of the postwar neo-Malthusian tracts, Road to Survival (1948), at a time when specialists still questioned the usefulness of family planning campaigns. And when Hugh Moore published a shrill neo-Malthusian tract in 1956, The Population Bomb, the IPPF welcomed him into its ranks while the population specialists tried to distance themselves from what they considered extremism (Piotrow 1973: 18-19). Strains also arose from differences in the power and financial strength of these two players (Stycos 1968: 25):

For decades in the United States, small organized groups of courageous women have been insisting that the health and social welfare of the woman depend on the ability rationally to regulate the number and timing of her births. 
Such arguments received the degree of respect and attention normally accorded to small organized groups of courageous women in the United States. At the same time, however, a handful of less vociferous but more influential men of affairs began to be concerned about the economic and political implications of world population growth, and in particular, about the growth of the under-developed areas. Their fears included Starvation, Unrest, War, and Communism. . . . When thrown together at an occasional conference, they regarded each other with the combined suspicions and hope of exploitation found only at a social function of Ivy League boys and townie girls.

Some population specialists at first doubted the usefulness of IPPF's "feminist" bias, worrying that providing contraception exclusively to women might lessen its acceptability in male-dominated societies. At Sanger's Cheltenham conference in 1948 Frank Lorimer proposed "isolating contraception from what he perceived to be the complicating and variable factors of gender relations and sexual ethics," and argued against the planned parenthood method of establishing family planning clinics for women (Chesler 1992: 410). Dudley Kirk, speaking to an IPPF audience in New Delhi in 1959, recommended that "male" methods of contraception, specifically condoms and withdrawal, be used in India in preference to expensive "female" ones that required a medical infrastructure (Chesler 1992: 451). J. Mayone Stycos complained that IPPF's feminist bias led to an “emphasis on female methods for female patients, and the justification of family planning largely in terms of its benefits for the female. . . . Even the most effective male methods are viewed with some suspicion" (1962: 481482). However, there was little evidence of male interest in using the methods at their disposal, such as withdrawal. Eventually, the population specialists agreed with their planned parenthood partners about the importance of female methods of birth control, and thus women became the "targets" of family planning programs (Watkins 1993).

Most population specialists came to view the IPPF's moderate feminist rationale for family planning as a valuable supplement to their economic and political arguments for fertility control. They were in no way pressured into accepting this position by a feminist social movement, since no such movement existed at the time. Acceptance was based on their belief that the traditional male-dominated social structures of agrarian societies were organized in ways that imposed high fertility. In such a context they came to hope that women might seek to control their fertility but simply lacked the means to do so. A family planning program might, therefore, fulfill a suppressed female demand for birth control. Although not interested in equalizing gender relations in third world societies, population specialists were looking for evidence that family planning programs would work in such societies. On this score, the mild feminist assumptions 
that informed the birth control movement-that all women desire to gain control of their reproductive destinies-provided grounds for optimism about lowering fertility at a time when few other reasons for such optimism could be discerned.

By 1960 both planned parenthood proponents and population specialists sensed that the American public was ready to support an overt neoMalthusian movement. Nobel laureates signed statements condemning the scourge of overpopulation that were then presented to the United Nations (Chesler 1992: 456-460). The Population Council published an explicit neoMalthusian tract, This Crowded World (Osborn 1960), aimed at a general audience. Both planned parenthood advocates and population specialists pressed for the United States to adopt an international neo-Malthusian policy, and there was growing optimism that this would soon occur. In 1963. Sanger, in one of her last public statements on population, expressed her deep satisfaction at the success of the neo-Malthusian movement (quoted in Chesler 1992: 462 ):

Fifty years ago I realized what was coming-the population explosion we hear so much about today, women having more and more babies until there's neither food nor room for them on earth. And I tried to do something about it. Now I have thousands of people all over the world aware of that problem and its only possible solutions-family limitation and planned parenthood.

The alliance that population specialists and birth controllers forged during the 1950 s was deep-seated. They shared an ideology and a demographic goal, much as Sanger and the eugenists had earlier. Both wished to bring birth control to the masses of the world's people who had limited access to modern methods of contraception. The birth controllers working for Planned Parenthood saw great benefit flowing to the individual, especially the individual woman, from having a smaller family. The neo-Malthusians were convinced that the resolution of societal and geopolitical crises required the lowering of birth rates. Their shared belief in the beneficial effects of lower fertility united the parties.

Some now contend (Gordon 1990: 386) that during this period the alliance between feminists and neo-Malthusians was lopsided, that neoMalthusianism overwhelmed the original feminist intent of the birth control movement:

Descended from Malthusianism, population control had distinctly separate roots from the U.S. birth-control movement. Yet Planned Parenthood, the organizational heir to the birth-control movement, married the two, in a union in which the birth-control "wife" was subordinated to the population control "husband." 
Margaret Sanger, however, might have disagreed with this assessment. Her espousal of neo-Malthusianism spanned many decades and is difficult to doubt. Over the period 1945 to 1965 most birth controllers and most population specialists became confident that inducing third world women to practice contraception would simultaneously improve these individuals' social and economic situation and alleviate societal problems. The contemporary concern that state population policies might encroach on the reproductive freedom of third world women was nowhere to be found. Not until a revived feminist movement began to question neo-Malthusian intentions would "wife" and "husband" overtly disagree. ${ }^{17}$

\section{Neo-Malthusianism and feminism, 1965-74: An alliance is questioned}

By the end of the 1950s the perception of the "population problem" had undergone a decided alteration. Emphasis shifted from population size to population growth rates, and the list of countries experiencing a problem expanded from Asia to include nearly all third world countries. Researchers (Coale and Hoover 1958; Enke 1963) developed models that quantified the economic cost of continued high fertility and found it substantial, at least in the short run. Departing from the colorless language of academics, in an unusual 1968 issue of Demography academics and foundation representatives alike spoke of the efforts to control third world population growth in the language of a battle, a holy war (Watkins 1993). Some were so convinced of the seriousness of a population crisis that there were calls to move "beyond family planning" (Davis 1967) -for example by instituting a tax on children or by paying individuals to be sterilized. Paul Ehrlich began his best-selling neo-Malthusian tract, The Population Bomb (1968), with a prediction of imminent global catastrophe: “The battle to feed all of humanity is over. In the 1970s and 1980s hundreds of millions of people will starve to death." Soon thereafter Paul and Anne Ehrlich proposed laws that "would make bearing a third child illegal and that would require an abortion to terminate all such pregnancies" (Ehrlich and Ehrlich 1972: 372).

Issues of coercion generated debate within the neo-Malthusian movement (Berelson 1969), and the Population Council hired an ethicist. The more drastic proposals to go "beyond family planning" (i.e., to introduce significant disincentives) were rejected within the population establishment, probably because they troubled some of its more influential members but also because such proposals were politically problematic. The immediate task was to convince nervous political leaders, both at home and abroad, of the practicality of fertility control. Suggestions that it might require highly coercive measures would hardly serve that purpose. Thus, the alliance between the neo-Malthusian movement and the international planned par- 
enthood movement continued to be characterized by a voluntaristic and mildly feminist stance. Many neo-Malthusians were troubled by the limited success that existing family planning programs such as India's were experiencing, but publicly they remained confident that if the "facts" of the case were presented effectively, women would realize that small families were good for the development of the country and also good for themselves. They therefore sanctioned propaganda campaigns aimed at fostering small-family norms as acceptable "eduçational" efforts, and considered the offering of modest material incentives to contraceptive acceptors to be an effective marketing tool. They blamed the drawbacks of available contraceptive techniques for the limited success of family planning programs, and the Population Council took the lead in developing female contraceptives (the copper IUD and then Norplant ${ }^{\star}$ ) that, unlike barrier methods and the contraceptive pill, did not require sustained motivation for use. An additional advantage of the IUD (and, later, injections of Depo-Provera) was that a woman could more easily use it "privately," without the knowledge of her spouse or other family members (Lande 1995)-although husbands and wives can disagree on whether this is an advantage or a problem (Watkins, Rutenberg, and Wilkinson, forthcoming).

The immediate aim of the alliance was to influence state policy. NeoMalthusianism had attracted support well beyond private foundations and had become a significant social movement. By 1970 over 88 percent of Americans believed that the world was experiencing a population problem, and over 70 percent thought that the United States was also (Westoff and McCarthy 1979). In two national fertility studies, in 1965 and 1970 , women who considered US population growth a serious problem expressed intentions for substantially smaller family sizes than those who were not concerned, as well as much larger reductions in these intentions between the two surveys (Preston 1986: 180). Foundations supported the establishment of nongovernmental organizations such as the Population Crisis Committee and Zero Population Growth that recruited members, raised funds, and lobbied the US government to become involved in molding demographic processes abroad. Senator Ernest Gruening launched hearings beginning in 1965, and Congressional support grew (Piotrow 1973). By 1965 President Lyndon Johnson cautiously brought the US government on board with the establishment of population offices in the Department of State and in the United States Agency for International Development (Green 1993: 305-308). Funding for USAID's population program expanded rapidly and Reimert Ravenholt, head of this program, argued for a policy to "inundate" third world countries with contraceptives (Donaldson 1990). In 1969 President Richard Nixon created the Commission on Population Growth and the American Future with John D. Rockefeller 3rd as its head. The Commission issued a fundamentally neo-Malthusian report (1972) rec- 
ommending "that the nation welcome and plan for a stabilized population." The Commission's recommendations of legalizing abortion and giving minors access to contraception without parental consent, however, aroused Roman Catholic opposition (McHugh 1984: 41 1-412) and President Nixon, facing reelection, disavowed the report when it was issued in May 1972.

Following its substantial success at influencing the US government, the alliance's attentions turned to the United Nations, whose collaboration would give legitimacy to global population control efforts and help avoid charges of imperialism. The Vietnam conflict had generated much antiAmerican feeling, and many third world governments were suspicious of the US government's motives for supporting global fertility control. In December 1974 Henry Kissinger directed the National Security Council to examine the "implications of worldwide population growth for U.S. security and overseas interests." The Council's secret National Security Study Memorandum 200 found that rapid population growth fostered political instability, and it identified 13 countries of "special U.S. political and strategic interest" where "population stabilization" policies should be pursued. ${ }^{18}$ The Memorandum recommended (Mumford 1994: 140) discretion: "The US can help to minimize charges of an imperialist motivation behind its support of population activities by repeatedly asserting that such support derives from a concern with: (a) the right of the individual couple to determine freely and responsibly their number and spacing of children ... and (b) the fundamental social and economic development of poor countries...." Where diplomatic relations were strained, the Memorandum suggested (Mumford 1994: 146) providing aid through "other donors and/or from private and international organizations (many of which receive contributions from AID)." The United Nations Fund for Population Activities, already established in 1969 largely as a result of US efforts, became a major conduit for US funds by the mid-1970s (Symonds and Carder 1973; Johnson 1987: 26-28).

By the end of the period, then, the neo-Malthusian movement had gone well beyond the limited efforts of the previous period. It was successful in influencing public opinion and attracting resources. It had gained as allies corporate leaders, academics with relevant scientific expertise, the US government with its deep pockets and security concerns, and, particularly important for a movement with international aims, the United Nations. A substantial number of third world governments had accepted neoMalthusian premises and had adopted fertility control programs. However, the feminist credentials of neo-Malthusians were about to be challenged.

Second-wave feminism, sparked by the publication of Betty Friedan's Feminine Mystique in 1963 and by the establishment of the National Organization for Women in 1965, shared with its predecessors earlier in the 
century an ideology aimed at the advancement of women. But there were shifts in feminist ideology and goals that in retrospect can be seen as barriers to an alliance between feminists and neo-Malthusians in this period. The revived feminist movement was part of an efflorescence of "new social movements," such as the civil rights movement and the protests against the war in Vietnam. Conditions (e.g., segregated schools, the draft) that previously had been defined as natural or at best unfortunate were redefined as injustices, and some took to the streets to make their voices heard, marching on Washington, burning draft cards, and shedding bras (Piven and Cloward 1977). The political mobilization tactics of the new protest movements were much in contrast to the orderly hierarchies of the neoMalthusian establishment.

The revived feminist movement demonstrated considerably more diversity during this period than did the neo-Malthusian movement. Liberal and radical members had distinct agendas, assessed the extent of women's subjugation differently, and sought different remedies to end it. Reproductive control fit well with the agendas of liberal feminists. Primarily concerned with domestic issues, their goal was to achieve equality for women in the workplace. To compete with men, women had to be able to coordinate family formation decisions with career needs. Whereas public advocacy for birth control had been judged politically risky by the leaders of the women's suffrage movement, now that the political context had changed liberal feminists considered support for birth control to be essential. The Supreme Court's 1965 decision, Griswold v. Connecticut, finally gave marriéd couples a constitutionally protected right to contraception. Eight years later the Court in Roe $v$. Wade dramatically expanded birth control rights to include abortion. For liberal feminists, then, the greater accessibility to contraception and abortion achieved in this period was a prerequisite for reaching their primary goals and was largely uncontroversial.

Population control, however, was controversial for the radical feminists, who-then as now-had different ideologies from those of liberal feminists. Feminist critiques of neo-Malthusianism in this period were "tributaries of a more general stream of agitation" (Snow and Benford 1992), ones that explicitly challenged the power and control of the white male establishment. US involvement in the Vietnam conflict revitalized the political Left. Alliances developed among these movements based on overlapping memberships and a common belief in the possibility of major social change (Bearman and Everett 1993). The neo-Malthusian movement, largely because of the close establishment ties it forged during the 1960s, was not part of this Left-leaning coalition of social movements. ${ }^{19}$ The neoMalthusian movement's interest in lowering the fertility of the world's poor women of color raised questions: black organizations viewed population control with suspicion, the more radical of them labeling it genocide 
(Bambara 1970; Weisbord 1975), and the antiwar Left saw it as a part of an imperialist strategy for third world pacification.

The neo-Malthusians' third world fertility control programs attracted concerted opposition from leftist feminists. Early in the 1970s Linda Gordon disparaged the post-World War II neo-Malthusian movement by tracing its roots to American eugenists who, she argued, in the 1940s had reframed their old beliefs into new, more palatable population control arguments (1974: 81-91). She portrayed postwar neo-Malthusians simply as eugenists who broadened their horizons beyond national boundaries and softened their rhetoric. Their goal was still to preserve "the hegemony of the most able of the old yankees," but now by limiting the numbers and influence of the world's nonwhite populations (Gordon 1974: 86). Bonnie Mass analyzed the "political economy of population control" and concluded that it was part of a strategy to preserve Western hegemony by controlling the wombs of third world women $(1972$ : 48-49; 1974; 1976).

These leftist feminists were not necessarily opposed to the idea of population control, but only to the reactionary purposes to which it was put. Gordon, for example, argued that reproduction can be controlled by the group for the good of the group (1974: 87): "Population control may be a reasonable part of any overall plan for economic development if it is democratically decided upon and administered." Mass (1976: 187) depicted socialist "birth planning" as a "scientific method" of determining the size of families: "How many children a woman has is based upon her own daily circumstances, her health, her ambitions and talents, the family's situation and society's needs." She held up as positive models of such planning the practices of Cuba, China, Vietnam, and the Soviet Union because of their emphasis on collective decisionmaking rather than on individual rights.

The attacks by radical feminists relied heavily on a general Marxist critique of population control, and appear to have provoked little response from members of the population control movement. For example, there is no reference to these concerns in Donaldson's (1990) comprehensive history of the population control movement. ${ }^{20}$ Why were feminist criticisms ignored? We suspect that the diversity within the feminist movement made it possible for neo-Malthusians to listen selectively to feminist voices. NeoMalthusians could note that American feminists of all persuasions supported access to reproductive control as a human right, as established in Griswold $v$. Connecticut and Roe v. Wade, and proposals for programs that went "beyond family planning" had been rejected within the population control establishment itself. The language of the liberal feminists relating reproductive control to enhanced women's status in the United States added another rationale for population policies and programs, one that was easily translated into third world terms, especially in the context of a growing UN interest in "Women in Development" programs (Kardam 1991). Radi- 
cal feminists could be dismissed: they spoke as outsiders, they had little scientific legitimacy, and they attacked the collaboration between US foundations and a repressive US government with anticapitalist rhetoric, thereby limiting their political support. More generally, perhaps, feminists were not yet considered to have the moral authority to speak for women as a category. This was to change.

\section{Neo-Malthusianism and feminism, 1974-85:} A growing divide

Not only radical feminists but also third world leaders questioned the motives behind first world interest in controlling their women's fertility. The World Population Conference at Bucharest in 1974 was planned by the leaders of the neo-Malthusian movement to be the international conference where consensus would form around their agenda (Finkle and Crane 1975: 87-88). Third world leaders resisted, however, contending that "development is the best contraceptive," and that increasing first world economic development aid would be a more welcome population control strategy than simply supporting fertility control programs. John D. Rockefeller 3rd used the occasion to publicly convert to this "developmentalist" position (Rockefeller 1974), and soon thereafter the Population Council also declared support for integrating all fertility control programs into comprehensive development programs (Population Council 1978). This was the first of a number of challenges that neo-Malthusians faced during this decade.

Adoption of a developmentalist position was a setback for the neoMalthusian movement. The call for development and fertility control to proceed together signified that international policymakers considered the population problem to be significantly less virulent than did the neo-Malthusians. Fertility control was not considered a prerequisite for development, but a concomitant policy intervention that simply would expedite the development process. This constituted a significant demotion for fertility control on the international agenda of needed policy interventions. Indeed, it gave succor to those who held that fertility decline was a consequence of the development process and not a catalyst, and that the only way to insure its occurrence was by the indirect route of promoting development. Such a vision of fertility decline as a necessary consequence, not cause, of larger societal changes was to provide the frame that feminists would modify for later use at the 1994 Cairo conference: fertility decline as a necessary consequence of the empowerment of women. Although nothing approaching this formulation of the relationship can be found in the Bucharest document, it did call for the equal participation of women in the economic, social, and political life of their countries, and specifically sought to increase women's education. 
Another move at Bucharest had perhaps even more significant implications for relations between neo-Malthusians and feminists. At Bucharest the international body eventually supported family planning, but the rationale was that of human rights rather than population control: "All couples and individuals have the basic right to decide freely and responsibly the number and spacing of their children." Adopting individual-rights rhetoric nicely deflected criticism of possible neocolonial motives for first world support of third world population control, and few neo-Malthusians objected to it. Although feminists were sparsely represented at this 1974 meeting, the position adopted by the international community was consistent with the reproductive agenda of American liberal feminists. ${ }^{21}$ It also became the cornerstone of future feminist attempts to influence international population policy.

If recognized as inherent, a right no longer needs to be legitimized by reference to its social utility. Many neo-Malthusians at Bucharest promoted an individual's right to reproductive autonomy as a pragmatic way of furthering fertility control. Their advocacy, however, necessarily diminished the legitimacy of shaping reproductive behavior to further societal interests (Demeny 1994: 8). If this individual right were recognized as absolute, all such attempts would become positively unethical. Although the language adopted at Bucharest melded freedom with responsibility when endowing individuals with the right to determine family size, the legitimacy of fertility reduction campaigns had begun to be questioned, and neo-Malthusians had participated in that process.

Although the international community at Bucharest affirmed the right of individuals to reproductive autonomy, during the next decade several countries, notably India and China, initiated coercive fertility control campaigns. Forced vasectomies in India and one-child campaigns that pressured pregnant women to undergo late-term abortions in China were state responses to a perceived population crisis, and these actions dismayed many. Neo-Malthusians had worked hard to generate an aura of crisis around population growth, and they became associated with these coercive state actions. Although Congress did increase US government funding for international population programs, the media attention given to coercive fertility control efforts, especially those employing abortion, made American politicians hesitant about offering unqualified support for population programs. The movement's major private sources of funds, the Rockefeller and Ford Foundations, both significantly reduced their allocations for such programs during this decade, thus making the movement more dependent on public funds (Caldwell and Caldwell 1986).

Finally, neo-Malthusianism suffered an ideological setback during this decade: a skepticism about the gravity of the population crisis grew among both experts and the public. The Green Revolution had lessened fears of famine, and trends in developing countries had yet to show an inverse 
relationship between population growth and per capita economic growth. Some began to contend (Simon 1977) that population growth was a stimulant to economic growth. In addition, and not necessarily closely associated with family planning policies and programs, declines in birth rates also spread to a significant number of developing countries. ${ }^{22}$ Public alarm over the possibility of a "population bomb" steadily diminished after the late 1960s (Wilmoth and Ball 1992: 635), and mass-movement neo-Malthusian organizations such as Zero Population Growth (ZPG) suffered declines in membership. The one bright spot for neo-Malthusianism was in the international arena: the number of developing countries adopting official antinatalist positions and implementing fertility control campaigns increased substantially (Barrett 1995). ${ }^{23}$

The decade following Roe $v$. Wade was challenging for feminists and neo-Malthusians alike. A strong "right-to-life" movement emerged in the United States that gained political sophistication and strength. Although not successful in their bid to outlaw abortion constitutionally, right-to-lifers successfully lobbied Congress in 1976 to pass the Hyde Amendment that banned the federal funding of abortions. The National Organization for Women and the National Abortion Rights Action League (NARAL) coordinated a unified pro-choice lobbying voice by opening an "information exchange" with Planned Parenthood and Zero Population Growth (Staggenborg 1991: 70). Abortion became perhaps the single most important symbol for American feminists, including those in the international neo-Malthusian movement. With the fading prospects of a sufficient number of states passing the Equal Rights Amendment to the Constitution, defending a woman's right to abortion became the goal that unified American feminists. For the first time American feminism had a core agenda that focused on a reproductive issue. Pursuit of that agenda in the international arena made extended engagement with neo-Malthusians likely.

The "term "reproductive rights" entered the feminist lexicon during this decade. Originally it was a counterpoint offered by leftist feminists to "abortion rights," one aimed at questioning how narrowly defined the feminist reproductive agenda should be. Leftist feminists asserted that women have more than just a right to legally obtain an abortion; they have full "reproductive rights" that include, in cases of need, a right to governmentsubsidized abortion, contraception, prenatal care, and early childhood health care. All women, including poor women, have the right to bear as many children as they wish and to have their own and their children's health needs ensured. "Right" was used in the socialist tradition, meaning an individual's just claim to something, be it food, shelter, health care, or abortion. Initially, socialist-feminists interpreted the challenge posed by the rightto-life movement as part of a broader attempt by the Right to "push back the democratic gains made by the civil rights, women's, and gay move- 
ments since the 1960s" (Clark and Wolfson 1984: 113). Their tactic was to counter this thrust with an "offensive movement" that would seek "the conditions for 'free choice,' including child care, national health care, high quality education, and a guaranteed income" (Staggenborg 1991: 111).

Liberal feminists used the term "abortion rights" from within the liberal tradition, meaning by "right" an individual's freedom to act without government restriction. They had a more focused agenda than socialistfeminists and sought a broad array of allies to help safeguard the legality of abortion. For instance, lobbyists for NOW and ZPG worked together to deter Congress from passing an antiabortion Constitutional amendment in 1973, and ZPG members were among the earliest board members of NARAL (Staggenborg 1991: 62, 191-192); ZPG arguments held that public funding for abortion was useful for population control agendas. By contrast, the National Women's Health Network (NWHN), established in 1975 and one of the earliest reproductive rights organizations, officially opposed "the use of arguments and policies on the abortion issue which stem from an analysis which suggests that population control is an element in the movement for reproductive rights" (Staggenborg 1991: 113-1 14). The NWHN also denounced those who sought support for public funding of abortions by arguing that it would limit welfare expenditures. The continued strength of the right-to-life movement, and its success at restricting women's access to abortion, have worked to maintain the liberal feminist agenda of simply protecting abortion rights. However, the more expansive term reproductive rights, divested of many of its original socialist connotations, has gained favor among a wide spectrum of American feminists. ${ }^{24}$

Actions by the more-activist women's groups to protect women's reproductive health gained widespread support among all feminists, as evidenced by the enormous popularity of Our Bodies, Ourselves, a book first published in 1971 by the Boston Women's Health Collective. The major concern of the NWHN, for example, was placing women's interests at the center of women's health care (Higer 1996). Physicians, medical researchers, pharmaceutical companies, and neo-Malthusians often had made decisions about women's health issues that NWHN members believed were not in the best interest of women. In 1977 the NWHN worked to get moreextensive warning labels put on prescriptions of birth control pills, an action fought by both pharmaceutical companies and neo-Malthusians (Gordon 1990: 422). Feminists won and pill use in the United States declined substantially. ${ }^{25}$ Feminist groups successfully fought to block approval by the Food and Drug Administration of Depo-Provera in 1978 and 1984, against opposition by Upjohn, USAID, and IPPF. After the Dalkon Shield IUD had been removed from the US market because of the high rates of infection and sterility it caused, feminists charged (Ehrenreich, Dowie, and Minkin 1979) that Ravenholt and USAID were dumping their supplies of 
the Shield in third world countries (Mintz 1985; Grant 1992). Some feminists argued for a return to barrier methods, or even to abstinence or withdrawal (Bram 1978; Greer 1984). Population specialists tried to normalize the risks associated with modern contraceptives with calculations that showed they were less than the risks associated with repeated childbearing, but the women's health movement made feminists very sensitive to issues of power and manipulation. ${ }^{26}$ The research efforts of pharmaceutical companies and neo-Malthusians might produce more "effective" contraceptives, but such improved efficiency, some feminists argued, often simply made it easier for these organizations to attain their goals without enhancing the reproductive rights of women.

The growing divide between the feminist reproductive agenda and the agenda of neo-Malthusians lessened the significance of what should have been a unifying event: the election of the economically and socially conservative Ronald Reagan in 1980. Reagan, and subsequently George Bush, provided them with a common enemy. Reagan's right-to-life positions were clear from the beginning of his presidency, and his election posed a serious threat to the feminist pro-choice agenda. His election forestalled implementation of the neo-Malthusian policies recommended in the Global 2000 Report, which the US Council on Environmental Quality and the US Department of State had delivered to President Carter in $1980,{ }^{27}$ and Reagan's anti-Malthusianism came clearly into view late in 1983 when designating the delegation that would represent the United States at the 1984 International Conference on Population in Mexico City. Any acknowledgment by the United States at that conference of a serious population problem very likely would be interpreted by social conservatives as an apology for abortion and state-mandated contraception, a position with which Reagan did not wish to be associated during an election year (Finkle and Crane 1985: 16-20). At Mexico City the US delegation asserted that "population is a neutral phenomenon" in the development process, and that excessive state control of the economy was more responsible for economic stagnation than rapid population growth. Adopting this anti-Malthusian position undercut the rationale for fertility control programs, and allowed the Reagan administration to oppose them and abortion. Although inspired by domestic political considerations, this position had concrete consequences for international neo-Malthusian efforts. After the Mexico City conference the United States stopped funding the foreign family planning activities of organizations that also provided abortion.

The position adopted by the Reagan administration should have fostered a strong alliance between neo-Malthusians and feminists. The Reagan amalgam of social and economic conservatism managed to reject simultaneously the legitimacy of a woman's right to abortion, preservation of which was the central goal of second-wave feminism, and of population control, 
the objective of neo-Malthusianism. The administration adopted policies that intentionally held hostage the access of millions of women to contraception in order to reduce abortion. Although pushed together by these actions, feminists and neo-Malthusians did not form an alliance. Reagan's amalgam of conservative positions actually exposed the different reproductive objectives of the two movements.

For instance, in response to the administration's positions the Population Division of USAID protected its funding and bureaucracy not only by isolating its family planning programs from all connection with abortion services, but also by elaborating non-population control rationales for them, designating them as components of maternal and child health programs (McPherson 1985) ${ }^{28}$ Reproductive rights feminists objected strenuously to USAID's abortion position, but viewed with some approval its display of anti-Malthusianism: "the Reagan Administration identified economic underdevelopment as the real problem, and excessive population growth as merely a symptom" (Dixon-Mueller 1987: 163-167). Many feminists actively endorsed the recasting of family planning as a health program: "Indeed, the emphasis within AID on the right of couples and families to control their own fertility, and on maternal and child health as the major justifications for international family planning assistance, provides a promising policy basis for stressing clients' needs, informed choice, and quality of care" (Dixon-Mueller 1987: 167). Population control programs engaging in practices such as enticing tubal ligation candidates with incentives faced concerted attack by feminists (Hartmann and Standing 1985), and problems of rapid population growth were not seen as warranting any infringement on the reproductive autonomy of women. Few feminists, therefore, objected to the waning of administration support for neo-Malthusianism.

Likewise, feminists could not rely on much neo-Malthusian support in their struggle for abortion rights. Abortion, a woman's ultimate means of controlling her reproductive destiny, was preeminently a feminist issue. At the population level, abortion is an expensive and not especially efficient means of limiting births. Neo-Malthusians, worried about cost-benefit ratios, never favored abortion as a means of birth control. Sterilization, with its permanence and limited need for motivation, held more appeal along with the IUD and long-lasting hormonal methods such as DepoProvera and Norplant. Of course, the attributes that attracted neo-Malthusians to these methods made feminists suspicious of them, especially sterilization (Shapiro 1985). Moreover, neo-Malthusians were less able to offer assistance to feminists in the domestic political arena during the 1980s since mass neo-Malthusian movements such as ZPG had faded considerably in strength and no longer were a major source of pro-choice votes.

The sharing of a common enemy, therefore, did not provide a sufficient foundation on which to build an alliance between feminists and neoMalthusians. Even so, the actions of the Reagan administration did en- 
courage renewed contact between feminists and neo-Malthusians, and gave birth to some organizations that bridged the two movements. In 1980 the Population Crisis Committee gave a grant to the National Women's Health Coalition, which was reconstituted as the International Women's Health Coalition (IWHC), to promote menstrual regulation and early-term abortion in developing countries. The IWHC, started with neo-Malthusian money, became the major source of support and training for third world providers of abortion. Soon it expanded its agenda and attempted to construct a firmer foundation for an alliance between feminists and neo-Malthusians.

\section{Neo-Malthusianism and feminism, 1985-95:}

\section{An alliance is assembled}

The story of the neo-Malthusian movement in this final period of analysis is largely a continuation of the trends since Bucharest: growing international strength, but domestic weakening. By 1991, 69 countries had officially endorsed comprehensive population policies (Barrett 1995: 249). Family planning programs continued to receive international funding, but an increasing proportion of funding was provided by third world governments themselves, indicating a growing neo-Malthusian commitment on their part. Domestically there was a steady erosion of institutional support for neoMalthusianism. Neo-Malthusians were asked for solid evidence that rapid population growth had significant negative effects on development potential. Such evidence had become more ambiguous, and the received wisdom of neo-Malthusians faced serious challenge on many fronts, from the opposition of the Religious Right to the skepticism of academics. A report by the National Academy of Sciences (National Research Council 1986) seriously weakened development rationales for population programs. Cold War fears had generated a good deal of political support for population reduction efforts for 40 years, but the collapse of the Soviet Union and the end of the Cold War dissipated this powerful source of neo-Malthusian support. Additionally, in the post-Cold War context the development argument for population control, at least for Northern policymakers, devolved into a humanitarian argument: population control will enhance the welfare of Southern individuals. Benefits that might accrue to the North from reducing Southern rates of population growth could be suggested: perhaps fertility reduction, by enhancing rates of economic growth in the South, would eventually lessen Southern emigration to the North or enhance South/North trade. These benefits, however, lacked immediacy and credibility. Altruism promised to provide a much shakier foundation for support for neoMalthusianism than fear of communism. The withdrawal of US executive branch backing for neo-Malthusianism elicited no revival of foundation support, and some old-line population officers in foundations were replaced by ones more attuned to feminist concerns. ${ }^{29}$ 
The extent and pace of fertility decline had increased. Although these fertility declines could be interpreted as evidence of the past success of fertility control programs, they also lessened the salience of population control on the international agenda. Demographic accounts told in terms of age composition and population momentum are technical, and much less capable of capturing the public imagination than the earlier projections of rapid population growth-with third world curves soaring upward much more steeply than those for the first world. Many neo-Malthusians believed that simply "satisfying existing demand for family planning" would bring further substantial declines, and population projections made during this period invariably assumed a continued decline in Southern population growth rates (Westoff 1994: 30, 32). Population policy became focused on reducing the ultimate size of the world's population by hastening the pace of fertility decline. Social problems compete for attention and funds (Hilgartner and Bosk 1988), and in this competition for salience population control issues lost while global environmental issues gained.

Neo-Malthusians reacted to declining interest by reshaping their agenda and, much as Sanger had done, by pragmatically casting around for possible allies. The environmental movement seemed an obvious source of support, given that one strand of explanation for environmental problems emphasized population growth (Crane 1993: 367-369): “Reducing population growth was readily incorporated into the concept of 'sustainable development,' which became the common aspiration of the environmental and development communities during the 1980s...." Prestigious scientific bodies such as the Royal Society of London and the US National Academy of Sciences issued statements (1992) linking current rates of population growth with "irreversible degradation of the environment." The senior vice president of Population Action International (formerly Population Crisis Committee) wrote in Foreign Policy that the next decade was the last chance to stabilize population "through humane and voluntary measures" (Camp 1993: 126). The director of Population Sciences at the Rockefeller Foundation testified to Congress that if governments do not adopt "voluntary and humane policies" to slow population growth in the present, it "can lead to a requirement in the future to try to control population growth rates in more Draconian ways" (Sinding 1994). Senator Al Gore published Earth in the Balance, declaring that "no goal is more crucial to healing the global environment than stabilizing human population" (1992: 307). These efforts to rejuvenate the population issue met with mixed success, and the neo-Malthusian effort to forge an alliance with the environmental movement was actively contested by feminists.

Women meeting in Rio de Janeiro in preparation for the 1992 UN Conference on Environment and Development objected vigorously and successfully to including population as a cause of environmental degradation 
(Cohen 1993). Two days of discussion on population were held at the Women's Tent outside the UNCED meetings, and population control was roundly attacked. The final Rio Declaration on environment and development contained only oblique mention of population..$^{30}$ Even so, some feminists feared that neo-Malthusians using aggregate environmental arguments would oppose their attempt to fashion a conference document unequivocally guaranteeing the reproductive rights of individual women at the Preparatory Committee meetings preceding Cairo. This did not happen. ${ }^{31}$ By the third Preparatory Committee Meeting for Cairo (PrepCom III) Susan Davis of the Women's Environment and Development Organization observed (1994): "the environmental constituency worked closely with the women's caucus; they coordinated their inputs." Apparently environmentalists, concerned with furthering their broad agenda, did not wish to alienate feminists by appearing to support any intrusion on women's reproductive rights. Nor did they wish to weaken ties with friends in the South who objected to blaming environmental degradation on the prolificness of the poor rather than on the overconsumption of the rich.

The new alliance that came to sustain the neo-Malthusian movement was with feminists, and was indeed largely initiated by feminists. Beginning in the mid-1980s, a network of feminists committed to improving women's reproductive health "played an increasingly influential role both in shaping the terms of the policy debate and re-orienting the population agendas of major international institutions" (Higer 1996: 1)..$^{32}$ They drew on the values expressed in the reproductive rights agenda that had been articulated in the abortion debates, particularly its human rights rationale. Unlike either the suffragists of the early years of the century or USAID in the Reagan-Bush years, both of which emphasized women as mothers, the reproductive health feminists envisioned women in a wide spectrum of social roles, a more expansive identity. They also drew on a wider feminist network, in part a consequence of more women attaining positions in foundations, nongovernmental organizations, and national and international agencies. ${ }^{33} \mathrm{An}$ inclusive ideology that valued wide participation and consensus-building produced an international network that included significant Southern representation. ${ }^{34}$

The International Women's Health Coalition took the lead in formulating a feminist position that made the alliance at Cairo possible, although its ideological frames, tactics, and influence owe much to previous developments in feminism as a social movement. In 1984 Joan Dunlop became president and Adrienne Germain vice president of the IWHC. ${ }^{35}$ Shortly thereafter its agenda expanded to include areas of women's reproductive health other than menstrual regulation and abortion, the initial focus of IWHC, and their funding sources shifted from the Population Crisis Committee to the Hewlett, Mellon, Ford, and MacArthur Foundations. ${ }^{36}$ Much 
as the neo-Malthusian movement had done earlier, the IWHC aimed to change state policy, particularly that of USAID, the Department of State, and the United Nations. Dunlop thought conditions were opportune for moving population policy in more feminist directions (Hartmann 1987: 295):

The threat of AIDS, which is renewing interest in barrier methods, and the right-wing attack on family planning, which is encouraging liberal elements in the population establishment to seek allies among the feminist community, make this an historic opening for those of us who want to make reproductive rights the new cornerstone of population policy.

USAID's recasting of family planning activities into maternal and child health activities suggested that the agency's program might be further transformed into a women's reproductive health program. This "reproductive health approach" was elaborated by Germain in a 1987 paper, "Reproductive health and dignity: Choices by third world women." Looking back on this paper from the perspective of May 1994, Germain (1994) said,

The vision ... now is a more encompassing vision. Back in ' 87 about the only thing we could really do would be to suggest that the different piecesMCH [maternal and child health], child survival, family planning-become more integrated. Seven years later we can write a vision which is much more encompassing and is actually well-reflected in the ICPD document.

Germain's 1987 paper listed the constituencies that might be approached for alliances, including "population professionals who want both to increase the number of contraceptive users and to support their continuing use for substantial enough periods to have both demographic and health effects. ${ }^{37}$ To woo these constituencies, the IWHC leaders had two tasks. First, they had to develop a feminist population policy that would satisfy a wide variety of feminists. Second, they had to mobilize support for this policy from the neo-Malthusian establishment.

Between 1987 and 1994 the IWHC articulated an "ideological package" that melded its own commitment to safeguarding and improving women's reproductive health with specific issues raised by feminists over the past 20 years. An early step was to reframe the concept of "unmet need." Demographers measure unmet need as the proportion of married women who say they want to stop childbearing or delay the birth of the next child but who are not currently using contraception (Westoff 1988; Bongaarts 1990, 1991). The existence of a significant proportion of such women provides justification for further family planning efforts (Sinding 1993). In Germain's 1987 paper unmet need was expanded to include wom- 
en, such as the unmarried, currently excluded from services. By 1994, however, feminists engaged in the effort to influence the Cairo Program of Action were using the term in a far more expansive fashion, one evocative of Emma Goldman, the early Margaret Sanger, and leftist-feminists calling for positive rights in the 1970s (Abzug 1994):

So, what should we emphasize in Cairo? First, we must collectively address
the challenge of how to meet the real unmet demand and need of billions of
people for simple human dignity and basic human rights. How do we meet
the unmet demand and need by the female half of our population for power
over their lives, for control over their bodies, for physical and emotional se-
curity, for education and economic independence that enables the realiza-
tion of one's human potential? And how do we meet the unmet consump-
tion demand and need for food, for shelter, for education, for jobs, for health
care?

In March 1993 the IWHC, acting as international secretariat, began circulating for signatures a policy statement, "Women's Voices '94" (International Women's Health Coalition 1993), aimed at insuring that women would be "heard" during the preparations for the International Conference on Population and Development in Cairo. "Women's Voices '94" illustrates how the ideological package of the international reproductive rights feminists was reframed after 1987. It includes the aims set out by Germain in her 1987 paper to improve and expand delivery of family planning services, ${ }^{38}$ but adds opposition to any form of coercion (such as the offering of incentives), advocates women organizing and running all programs providing health services for women, and calls for "equal rights legislation" to insure women better access to education, employment, and credit. Both liberal feminist concerns with gender equality and radical feminist concerns with the abolishment of patriarchy are addressed, suggesting a variety of influences from second-wave feminism. Over 2,200 individuals eventually signed the statement. ${ }^{39}$

The expansion of the feminist population agenda facilitated alliances with a wider range of feminists than had been possible before. The more visible of these allies during the preparations for Cairo was the Women's Environment and Development Organization (WEDO), a New York-based group led by former Congresswoman Bella Abzug. Among the resources offered by WEDO was the mobilization of support by Southern women. In November 1991 WEDO organized a "World Women's Congress for a Healthy Planet" in Miami attended by some 1,500 women from 83 countries, a mobilization that enhanced WEDO's presence at the Rio UNCED conference during June 1992. Whereas IWHC's tactics were to work in the corridors of power, WEDO's tactics were more reminiscent of the grass- 
roots collective action developed by the new social movements of the late 1960s and 1970s. Susan Davis, executive director of WEDO, described (1994) what has become the group's technique for representing women's interests at UN conferences:

It is a methodology to organize lots of people's energies for a "common ground" advocacy and to influence the process. It requires an understanding of the UN process and where the points of leverage are... . Women a decade ago wouldn't have understood that. It wasn't widely understood. It is now. And there wasn't a concerted effort to harness lots of voices.

Harnessing "lots of voices" was an implicit challenge to the white male neo-Malthusian establishment continuing to decide what was best for third world women. The tactic, however, posed problems for IWHC leaders who wanted to work with that establishment to plan for Cairo. Many of the Southern women at the UNCED meetings were actively hostile to all talk of population problems, and had displayed a willingness to confront openly those who thought otherwise. ${ }^{40} \mathrm{~A}$ repeat of the UNCED Women's Tent antiMalthusian display at Cairo was not what moderate reproductive health activists wanted. The Ford Foundation gave funds to the IWHC to bring together in January 1994 over 200 women activists, many with radical leanings, to see whether a unified Cairo strategy could be forged. Five days of meetings in Rio de Janeiro produced a "Rio Statement" on reproductive health and justice (International Women's Health Coalition 1994) that was notably more anti-population control than the original "Women's Voices '94" statement, even observing that "a significant number of the participants opposed population policies as being inherently coercive." ${ }^{\text {"41 }}$ It declared "unanimous opposition to designing fertility control measures or population policies specifically targeted at Southern countries," and explicitly questioned the safety of non-barrier methods of contraception. But, in the end, the participants did agree that women should come to PrepCom III and Cairo with a united voice and work to effect change within the limits of conference procedures.

An overt dismissal of the population problem could not be incorporated into a "common ground" position that was to serve as a basis for an alliance between feminists and neo-Malthusians. Although crisis rhetoric had diminished, neo-Malthusianism had not died. Prestigious journals such as Science were publishing articles with neo-Malthusian conclusions: "there is broad agreement that reduction in rapid population growth in the developing world will enhance the prospects for improved living standards of additional billions in the decades ahead" (Bongaarts 1994: 771). And some academics (Kelley and Schmidt 1994) were discovering evidence of negative correlation between aggregate population growth and per capita out- 
put growth for the 1980s. Likewise, a policy that explicitly attempted to lower the fertility of individual women also could not be incorporated into a common ground position, since feminists would object. A policy with which both feminists and the neo-Malthusian establishment could live needed to be devised as Cairo approached. Steven Sinding, of the Rockefeller Foundation, suggested abolishing all demographic targets and having programs that solely attempted to "meet the unmet need" of women for family planning (1993; Sinding, Ross, and Rosenfield 1994). His analysis of survey data indicated that every country's fertility targets would be reached if women attained their own fertility goals. Earlier Marge Berer, editor of Reproductive Health Matters, had called on women's health activists to "acknowledge that the world cannot sustain an unlimited number of people," and then urged them to become a major force in formulating population policies: "I would argue that women have a right to judge population policies as being acceptable or not, according to whether or not they meet women's needs and promote women's interests" (1991: 3). An advertisement placed by the IWHC in the New York Times (10 May 1993) made the connection between women as population actors and population policymakers, while also acknowledging that there was a problem in need of solutions: "Who is better qualified to come up with solutions than the women at the heart of the matter? No one." Such claims would have had little impact before second-wave feminism, but after three decades of feminist consciousness-raising in US society they had achieved a moral legitimacy that was difficult to dismiss.

Ruth Dixon-Mueller (1993) and others (Sen, Germain, and Chen 1994) constructed an elaborate and finely aligned "feminist population policy" within which feminist objectives were congruent with the interests of the neo-Malthusian movement. There were three crucial aspects of Dixon-Mueller's formulation. First, "population stabilization" was presented as a desirable ultimate goal, although not one warranting the use of compulsion. Second, national programs enhancing access to contraception were justified in terms of individual human rights, not in terms of their development advantages for aggregate populations. This shift, signaled earlier at Bucharest, allowed feminists to draw on the powerful symbolic human rights language embedded in UN rhetoric for decades to argue for the recognition of reproductive rights. Third, in an argument reminiscent of the one made at Bucharest that "development is the best contraceptive," the empowerment of women was presented as a prerequisite for the enduring low fertility that population stabilization requires. In this ideological package feminists reject both the legitimacy and the effectiveness of current efforts to induce women to have fewer children, arguing that only by redressing gender inequity and scrupulously respecting each woman's reproductive rights can lasting low fertility be achieved. Programmatically, 
this meant that family planning services should be provided within the context of comprehensive reproductive health programs that had enhancing health, not lowering fertility, as their fundamental objective. Only within such programs could contraception be provided to women without the appearance of manipulation.

This "common ground" population position was framed to accommodate many parties, including representatives of organizations that had strongly supported neo-Malthusian initiatives in the 1960s and 1970s. It worked. Joseph Speidel, president of Population Action International, observed (Greene 1994: 7): "there is growing recognition that there's a tremendous amount of common ground among what's been loosely called the health advocates, coming from a more feminist perspective, and traditional family planners, who come from more of a demography, environment, and development perspective." ${ }^{\prime 2}$ Steven Sinding testified (4 August 1994) before Congress that along with the provision of reproductive health services, "investments in the empowerment of women, particularly through education," are needed to bring about fertility decline. Lewis Preston, president of the World Bank, issued (6 September 1994) a three-part "Call to Action" that entailed improving women's access to health care and education as well as to family planning services. Even nongovernmental organizations that were focused on population control, such as Zero Population Growth and the Population Institute, incorporated much of the rhetoric in their public positions. Susan Davis of WEDO noted (1994) that by PrepCom III, ZPG actually "coordinated their inputs with us."

An alliance with feminists had aspects that appealed to neo-Malthusians. It came with a preexisting constituency, one that had been among the most vocal critics of the population control movement. Also, within this new framework justification for population control no longer rested on the changing theories and inconstant analyses of economists and ecologists. In fact, the familiar correlations of women's education with lower fertility were the only "hard data" many needed to document the claim that women's empowerment would lead to population stabilization. In the climate of the 1990s, ensuring women's reproductive health rights did not need even this empirical "proof" of its population control efficacy, much as an earlier generation of neo-Malthusians had not initially needed demonstration of the link between development and population control. If improving women's access to education or to reproductive health services did not result in dramatic fertility reductions, these endeavors would nevertheless be seen as intrinsically valuable. For feminists, at any rate, the salience of gender equity was viscerally felt.

The neo-Malthusian movement's shifting alliances played themselves out in a condensed version after the election of President Bill Clinton in 1992. Upon assuming office he immediately rescinded Reagan's "Mexico 
City" policy. He restored financing to IPPF and the United Nations Population Fund, adopted an unequivocal pro-choice position, and rejected the idea that population growth was "a neutral phenomenon" in the development process. He appointed Timothy E. Wirth Counselor at the State Department and the administration's main spokesman on population policy, and put him in charge of preparing for the Cairo conference. A former Senator from Colorado, Wirth had a reputation as an environmentalist who would strongly advocate population control as a means of restoring ecological balance. He soon discovered, however, that in the 1990s one had to be very careful when mixing neo-Malthusianism, environmentalism, and feminism.

The reproductive health feminists initially found Wirth "to be coming to this issue from an environmental concern" (Germain 1994) and spent the next year educating him about an expansive view of population issues that recognized the importance of delivering family planning services within a broader context of reproductive health and that emphasized the major role played by the empowerment of women in fertility decline. Wirth eventually converted. He asserted (ICPD 94 1994) at a March 1994 UN meeting that "sustainable development cannot be realized without the full engagement and complete empowerment of women," and noted that "women's empowerment, rights and well-being" were "top priorities for the Clinton administration." He ratified essentially feminist goals for the Cairo conference: "meeting the unmet demand for and expanding the range of reproductive health services"; "investing in the wisdom of women"; respecting "the basic human rights of women"; ensuring that "women have necessary economic rights"; adapting population programs "to address the unique problems faced by adolescent girls"; and involving women "in the design and implementation of sustainable development strategies and programmes."

By the time delegates met at the 1994 ICPD meeting in Cairo, a group of American reproductive health feminists had been successful in uniting a large bloc of feminists and much of the population establishment behind the carefully constructed "common ground" agenda. ${ }^{43}$ The Program of Action adopted at Cairo was the contract outlining the terms of a new alliance: redressing gender inequities is needed for lasting fertility control, and women have reproductive rights to freely determine their reproductive destinies. Both government and foundation components of the US neo-Malthusian establishment signed on, as did some UN members whose feminist credentials might be considered dubious. Although we had expected Cairo would be a battleground where feminists and neo-Malthusians would fight over framing the world's population agenda for the coming decades, a measure of the alliance's success was that only soothing words of agreement passed between the two new allies, who found themselves comrades in arms in a fierce battle with a Vatican delegation intent upon cleansing the Program of Action of any endorsement of abortion. The Vatican assumed 
that Americans largely shaped the Conference's agenda-an assumption shared by the Conference's secretary general (Sadik 1996): "it was American leadership above all which drove the Cairo process along" - and made a concerted effort to influence the US position. ${ }^{44}$ The press highlighted every skirmish in this battle, but hardly noticed the lack of conflict that surrounded the retraction of population concerns from that document. AIthough some conservative groups, such as the American Heritage Foundation, had come prepared to debate the existence of a "population problem," they found virtually no one with whom to argue. The absence of neo-Malthusian rhetoric in the Program of Action, in formal statements, or even in hallway discussions, made Cairo seem more a conference on feminism than one on population stabilization. ${ }^{45}$

\section{Neo-Malthusianism and feminism after Cairo: A lasting alliance?}

Historically, alliances between American neo-Malthusians and feminists have lasted when the two social movements agreed on certain ideological premises, shared a common demographic goal, and perceived mutual benefit in the alliance. The alliances entered into by Margaret Sanger's birth controllers and eugenists during the 1920s, and by planned parenthood advocates and neoMalthusians after World War II each possessed these characteristics, and each lasted well over a decade. One way to assess the likely durability of the current alliance, then, is to examine the extent to which the two parties agree on ideological premises, share goals, and perceive mutual benefit in the alliance.

\section{Shared ideology?}

In the 1920s birth controllers and eugenists shared a conviction that benefits would follow if the "less fit" had fewer children. In the 1950 s population specialists and planned parenthood advocates shared neo-Malthusian beliefs in the benefits of low fertility. Shared ideology fostered the trust that allowed actions to be coordinated and misunderstandings to be negotiated. Is there a shared ideology that unites contemporary neo-Malthusians and feminists? Our answer is no.

The major ideological divide has been clearly identified by both feminists and neo-Malthusians. For instance, at PrepCom III Bella Abzug, WEDO's president, explicitly called on all parties to repudiate neo-Malthusian ends and adopt feminist ones (1994):

We must ask the means-end question because the rhetoric in this document is better and better. But have the ends changed? Have we achieved a new shared understanding that populationist ends are the wrong end? Is women's 
equality a fundamental end, in and of itself? Or is the only reason any government or international agency now spends an additional dollar to educate a girl simply to persuade her to have fewer children? Are these concessions to 'women's empowerment' just more carrots?

Charles Westoff (1995: 15) agreed that the ends remained different: "The [ICPD] conference was a resounding success for the advocates of women's reproductive health but a disappointment to many concerned about population growth. And the two are not synonymous." Malcolm Potts (1995: 4) pointed to the same ideological divide that Abzug saw: “women's advocates rather reluctantly accepted expressions of concern over population growth into the Cairo document," and when considering fertility control they "often implied that success is impossible without coercion."

No neo-Malthusian openly attacked the gender equity goals of the feminists, and few were as intrepid as Potts and Westoff in risking the wrath of the reproductive rights feminists by questioning the common ground agenda. The lack of overt opposition actually aroused feminist suspicions. Elizabeth McGrory, a feminist who has worked on population issues at the Ford and MacArthur Foundations, grew wary after PrepCom III victories (1994): "Is it actually succeeding, or are they co-opting our language and kind of lulling us into a false sense of security when in fact they are not going to do any of this? 'They' being the white, male, population control establishment." Meanwhile other feminists, especially those who stood outside the common ground, carried forth the radical feminist critique of population control initiated by Gordon and Mass in the 1970s. Betsy Hartmann accused "the population control establishment" of consciously incorporating "the language of women's rights into its technocratic lexicon" as an "expedient" measure "to bypass the more politically sensitive issues of race and class." She noted that "to reduce population growth, they are willing to call for the education of women, for example, but not for land reform, the redistribution of economic and political power, or the repudiation of international debt" (Hartmann 1990: 45-46). ${ }^{46}$ Radical feminists abroad echoed these concerns: "Reproductive rights," Akhter asserted (1992: 5), "is nothing but the slogan for population control in disguise," and all population control "is based on eugenic, racist, sexist, and exploitative actions against certain races and classes of people." She wondered, "how can feminists take part in such exploitative policy?"47

In truth, many of the internationally oriented American feminists who participated in forming this alliance are overt anti-Malthusians. When a movement's purported ally can publicly ask it to repudiate its basic belief system at an international conference called to deal with that movement's agenda, as Bella Abzug did, it seems fair to say that there is little true sharing of ideology. 


\section{Common goals?}

The goals of contemporary neo-Malthusians and feminists derive from their ideologies. American neo-Malthusians wish to lower fertility so as to reduce population growth and thereby foster prosperity. American feminists wish to enhance the control each woman has over her reproduction as a means to gender equity and gender equality. The Cairo alliance finesses this disagreement over goals with a clever "common ground" agenda that fabricates a set of common goals. Both parties commit themselves to two provisions: a gender equity strategy for attaining population stabilization, and respect for the right of each woman to freely determine her fertility. Only within this artfully arranged set of common goals are the two movements compatible. But if either party comes to feel unduly constrained by this agenda, the alliance is likely to flounder.

The first provision of the "common ground" agenda, adopting a gender equity strategy for attaining population stabilization, presents the neoMalthusian with a significant problem: identifying a difficult-to-accomplish "means" as being the movement's principal way of attaining its desired end. If restructuring gender roles is slow to happen, neo-Malthusians will be tempted to seek alternative means of inducing fertility decline. If fertility decline occurs unaccompanied by significant changes in gender relations, as has happened in the past, neo-Malthusians will be tempted to stop working to end gender inequities. Either action is likely to rupture the alliance with feminists.

Neo-Malthusians also face problems if they abide with the "common ground" position's second provision, recognizing an inviolate right of each woman to freely determine her fertility. A genuine adoption of a reproductive rights framework entails forgetting decades of neo-Malthusian ideology. If an individual woman has "an absolute right to bodily integrity and to decide herself on matters of sexuality and childbearing with no interference from her partner, family, health care professionals, religious groups, the state, or any other actor" (Boland, Rao, and Zeidenstein 1994: 100), then any attempt to persuade her, with words or incentives, of the benefits of a small family would be inappropriate. Acceptance of this second provision might even inhibit neo-Malthusians from asserting the efficacy of birth control activities at the societal level. Might feminists construe, for example, lobbying for special funds for family planning activities as an infringement of reproductive rights, or a departure from the gender equity route to fertility decline? If their alliance with feminists keeps neoMalthusians from publicly proclaiming the efficacy of lowering fertility, they ultimately may be compelled to choose between preserving this alliance and preserving their movement.

If feminists accept as legitimate any infringement on reproductive autonomy, neo-Malthusians can much more easily justify their attempts to 
influence individual fertility decisions directly. But situations are arising, both domestically and internationally, that are testing the depth of feminist dedication to reproductive rights. Domestically, a number of "welfare reform" initiatives have been initiated that purposely restrict taxpayer support for unwed teenage mothers in order to reduce out-of-wedlock births. Feminists have mobilized surprisingly little opposition to this obvious infringement of their concept of reproductive autonomy. This muted response suggests superficial support for reproductive rights among middle-class feminists. With their own family-size decisions constrained by economic considerations, many might accept the notion that one should have only the children for whom one can provide. As such proposals become law with minimal protest, neo-Malthusians are in a position to draw obvious analogies: efforts to control the fertility of overseas populations receiving significant aid from US taxpayers are justifiable. Internationally, the practice of many couples aborting female fetuses in order to give birth to more sons has made it difficult for any feminist to absolutely support the individual's reproductive autonomy. Although reproductive rights feminists theoretically are opposed to any form of coercion, they worked hard to include in the Program of Action (4.23) a call for state intervention to stop such prenatal sex selection. The document offers no reason why individuals should not be able to choose the sex of their offspring. The stated objection to current practice is found in the gender imbalance of aborted fetuses, not in the practice itself. ${ }^{48}$ Such apparent approval of reproductive coercion to accomplish feminist gender-equity goals makes it less than obvious why reproductive coercion to accomplish the development goals of neo-Malthusians should be considered necessarily unethical.

Finally, both parties to this alliance live in a culture that accepts the importance of evidence produced by positivist science, and much of the "common ground" agenda rests on a less than firm scientific basis. Demographers (McNicoll 1994: 659; Cleland 1996: 110), for example, know of numerous counter-examples to the empirical generalization on which the Program of Action's population stabilization program is founded: that gender equity is a prerequisite of low fertility. Neo-Malthusians, who had never lost faith in the efficacy of their fertility control programs, now find themselves resting their movement's fate on a questionable empirical proposition. Likewise, feminists have taken an anti-Malthusian stance for a quarter-century and are very familiar with the empirical studies whose findings question the link between rapid population growth and stagnant economic growth. Their acquiescence to the Program of Action's goal of population stabilization, therefore, does not derive from any empirical judgment that such a stabilization would improve the circumstances of Southern women. Adrienne Germain of the IWHC admits as much (1994): "Our constituency includes, probably by far the majority, those who really don't think it [population] is a problem." Real questions exist, then, both about the ex- 
tent to which the "common ground" agenda incorporates the true goals of each movement, and about the level of each movement's commitment to that agenda. If population stabilization is achieved without greater gender equity, feminists cannot be counted on to celebrate. If greater gender equity is secured without fertility decline, neo-Malthusians cannot be assured of applauding.

\section{Mutual benefit?}

In the 1920s eugenists appreciated a birth control ally that could market contraception to the lower classes as a way to improve health and wellbeing, and birth controllers appreciated the scientific credentials that a eugenist ally could lend to the cause of legalizing access to contraception. In the 1950s population specialists appreciated the optimism and fervor that planned parenthood advocates brought to their efforts, and planned parenthood advocates appreciated the global networks and resources of their ally. With real mutual benefits, both parties were motivated to preserve and strengthen their alliance. What, then, are the mutual benefits in the current alliance between neo-Malthusians and feminists?

Leaving aside help in attaining broad feminist goals such as investing in women or ensuring women's economic rights, reproductive health feminists have a specific agenda: to improve existing maternal and child health programs, including family planning; to include unmarried women and adolescents as clients; to establish programs to prevent and treat reproductive tract infections, sexually transmitted diseases, HIV, and breast cancer; to provide access to abortion; to discourage female genital mutilation; and to educate for a satisfying sex life (Dixon-Mueller 1993: 207; Program of Action: 7.6). They have two ways of attaining these specific goals: generating de novo their own stream of funding and establishing a service delivery structure in collaboration with Southern governments, as the neo-Malthusians had done in previous decades; or piggy-backing on the funding, bureaucracies, and clinics of the neo-Malthusian movement. The latter strategy is attractive because the population movement's resources and institutional structures are substantial. From the point of view of the reproductive health feminists, then, an alliance with neo-Malthusians has much to offer.

What do neo-Malthusians want from this alliance? There seem to be few material benefits for neo-Malthusians in an alliance that redirects significant amounts of their funds and institutional power to reproductive health feminists. Speaking in May 1994, Germain noted this pragmatic concern of neo-Malthusians: "There is a fear, there is a real threat now, there is a demand that we want to do something different with their money." Some neo-Malthusians see an ideological benefit flowing from an alliance with feminists. Reframing family planning programs as reproductive health programs, and population control programs as gender equity programs, pro- 
vides a more "politically correct" rationale for fertility control. Alternatively, the political clout of feminism has made it difficult for neo-Malthusians to rebuff overt feminist attempts to reframe population policy without opening themselves up to charges of being sexists, an epithet few wish to endure these days.

Any consideration of benefits also must examine risks. There are material risks for neo-Malthusians in collaborating with feminists. If public support for the reproductive rights of Southern women is insufficient to motivate Northern donors to fund new reproductive health services and keep appropriations for family planning at current levels, then funds available for family planning may actually decline. ${ }^{49}$ If antifeminist sentiment gains strength, perhaps in conjunction with Presidential or Congressional elections, then neo-Malthusians could see their interests politically threatened by this alliance. In January 1996 a group of abortion opponents in the House of Representatives managed to cut the population and family planning budget of USAID for fiscal year 1996 to only 14 percent of fiscal year 1995 expenditures. These representatives wanted a reinstatement of the Reagan-Bush restrictions on US-funded groups using private money or money provided by other governments for abortion-related activities. To the extent that preserving pro-choice options in international family planning programs is primarily a feminist concern, neo-Malthusians experienced in a dramatic fashion the costs of an alliance with feminists (Potts 1996). Although the 1996 elections weakened Congressional antiabortion forces and ended the "embargo" on international family planning funds, the future is uncertain. If neo-Malthusians were unencumbered by alliance with feminists, their ability to negotiate with social conservatives would be enhanced. ${ }^{50}$

There are ideological risks for feminists in an alliance with neo-Malthusians. To the extent this alliance is a pragmatic move by feminists to redirect some of the population establishment's resources to women's health programs by playing on the Malthusian fears of rich nations (Germain 1994), then "common ground" feminists should acknowledge the seriousness of the population problem simply to sustain the flow of funds. Yet such an acknowledgment portends movement discord. Radical feminists have always offered broad interpretations of North/South, rich/poor, and male/ female relationships that identify differential power as the major source of mistreatment and hardship. They see overpopulation explanations of poverty as attributing the plight of poor women to their own actions. "Common ground" feminists, therefore, find themselves pulled in different directions by a desire for resources and by a worry over movement discord. They must be Malthusian enough to effectively solicit funds, but antiMalthusian enough to preserve ties with more radical feminists, both at home and abroad, who remain staunch opponents of population control. 
The cost and benefit ledger of this alliance for each movement is still indecipherable. Only after a number of funding decisions are made will it be clear whether mutual benefits are associated with this alliance. Presently, its mutually beneficial character is suspect. If Northern funding for reproductive health services is not forthcoming, feminists are likely to seek movement unity and retake the anti-Malthusian high ground. If close ties with feminists and the abortion issue significantly reduce the level of funds available for fertility control programs, neo-Malthusians are likely to begin distancing themselves from feminist positions.

\section{Conclusion}

Neo-Malthusians, and those who seek to influence population trends generally, are neither natural allies of feminists nor natural enemies: much depends on the circumstances of the moment. The birth control movement under Margaret Sanger and her successors was clearly a feminist endeavor, one asserting that a woman's ability to control her reproduction was a prerequisite for women's equality. It formed sturdy alliances first with the eugenists in the 1920s, and then, when eugenics came into disrepute, with neo-Malthusians in the 1950s. These alliances were based on shared ideological beliefs and demographic goals, and were perceived to be mutually beneficial. In the 1980s, however, American feminists encountered an American neo-Malthusian movement diminished in power and influence, and fashioned a one-sided "common ground" agenda that produced an alliance of questionable mutual benefit. Based on a fabricated unity of interests that neither movement finds convincing, this agenda is unlikely to bind together two movements that share few ideological beliefs and possess no clear common goals. Our historical analysis suggests that the contemporary alliance between American neo-Malthusians and American feminists is a fragile one, unlikely to endure any change in circumstance.

One change, however, might work to maintain this alliance into the twenty-first century: the growth and consolidation of global society. Although our account of the formulation of the Program of Action emphasized the preeminent role assumed by Northern, especially American, participants, we believe that at future conferences on population, power will move from the North to the South. Southern countries are no longer passive recipients of population control largess; many now fund a substantial majority of their own reproductive health services. In most Southern countries a different dynamic exists between national neo-Malthusian and feminist movements than exists in the United States. Many Southern governments are currently staffed with officials who hold strong neo-Malthusian beliefs. Malawi and China (Malawi Government 1995; Chinese Government 1996), for example, recently adopted unreconstructed population con- 
trol documents. Feminism is generally less well established in Southern countries, especially outside the capital cities. If Southern officials find that pragmatically relabeling family planning programs as "reproductive health programs" and AIDS prevention programs as "sexual health programs" induces donors to fund their requests for assistance, then strong international support for the Program of Action might develop. A "common ground" agenda that pragmatically works to fulfill the material needs of highly placed Southern neo-Malthusians and the ideological needs of influential Northern feminists might also work to keep alive a fragile domestic alliance between unequal partners.

\section{Notes}

Versions of this article were presented at the 1996 Population Association of America Meeting and the 1995 Social Science History Association Meeting. We are grateful for comments from Deborah Barrett, for conversations with José Barzelatto, Judith Bruce, Lynn Freedman, Amy Higer, Carolyn Makinson, Faith Mitchell, Shara Neidell, Steven Sinding, Sylvia Tesh, Nahid Toubia, and Charles Westoff, and for interviews with Barbara Crane, Susan Davis, Joan Dunlop, Adrienne Germain, Margaret Hempel, Elizabeth McGrory, and Thomas Merrick.

1 For the purposes of this article, we consider both feminism and neo-Malthusianism to be social movements. The definition of a social movement is contested. "Social movements are often described as collective responses to a group's experience of subordination" (Buechler 1990: 9), responses that are often directed at the state. This definition fits feminism well, but the neo-Malthusian movement less well, since, like the temperance movement or the environmental movement, it is a collective response to the behavior of other groups or to conditions that affect many. (For an introduction to the social movement literature, see McCarthy and Zald 1977; Piven and Cloward 1977; McAdam 1982; Buechler 1990; Morris and Mueller 1992; and Dalton and Kuechler 1990). Currently, the two dominant perspectives on social movements are those of the politics of resource mobilization and the politics of identity. The first privileges formal organizations and their at- tempts to mobilize resources (including funds, members, and allies): the second privileges more broadly social movement communities, including those who may be members of a social movement by virtue of their shared values (peace, the environment, feminism) but may not be associated with any movement organization. We draw from both perspectives. Because the Cairo document was the product of formal organizations, we focus on the behavior of organizations, although we point out that the concept of a feminist identity is important in understanding the behavior of feminist organizations in elaborating and promoting a feminist population policy.

2 In privileging ideologies, we recognize that we are ignoring many other aspects of social movements. One important aspect is the degree to which a social movement is institutionalized, with organizational structures, bureaucracies, and budgets. At the time of the Cairo conference the population movement had more elaborate structures, larger bureaucracies, and larger budgets than the feminist reproductive heaith movement. The institutionalization of these social movements is clearly an area that needs more detailed research. As we suggest later, however, one incentive for some members of the population movement to ally themselves with the feminists may have been to attempt to preserve these structures, bureaucracies, and budgets in the face of declining interest within the United States in third world population growth. 
3 We have found little in the literature about the process by which alliances among social movements are formed or dissolved, although there is considerable evidence (especially regarding the "New Social Movements" of the 1960s and 1970s) that social movements influence one another (see, for example, Meyer and Whittier 1994).

4 The word "feminism" came into frequent use during the 1910s, at the height of the suffrage movement (Cott 1987: 3): "The new language of Feminism marked the end of the woman movement and the embarkation on a modern agenda." Today the term has taken on additional connotations for some, and we recognize that many of the women and men whom we label as "feminists" might not identify themselves as such. We use the term simply to refer to those who seek greater equality between men and women.

5 Although some have questioned birth controllers' feminist credentials, we consider them to have been protagonists of a pragmatic feminist movement that considered a woman's control over reproduction to be a prerequisite for gender equality. Margaret Sanger fashioned a birth control movement that is difficult to classify since it employed both feminist and population control rhetoric. Some believe (e.g., Gordon 1976, 1990) that Sanger's break with the Left and her adoption of population control doctrines entailed a desertion of feminism. They consider the doctor-staffed birth control clinics that Sanger established with the contributions of society-women as charities aimed at reducing the poor's fertility, not true self-help organizations for women. Others (e.g., Chesler 1992), embracing Sanger's contention that control over reproduction must precede meaningful enhancement of women's status, place Sanger high on the list of twentieth-century feminists. We find Sanger to be a pragmatic feminist whose goal was to secure for American women the legal right to contraception.

6 Nafis Sadik, Executive Director of the United Nations Population Fund, expressed this point (1996) succinctly:

American leaders were among the first to state that there is a link between population and poverty; American women have led the fight for autonomy and equality. America was the driving force behind setting up UNFPA; America has historically been the biggest supporter of population and development programmes, and it was American leadership above all which drove the Cairo process along and brought it to a successful conclusion.

7 An important issue that we do not address in this article is the impact of population policy. As one reviewer, who is unconvinced that it does have an impact, said: “dogs bark and the caravan progresses." To speak to this issue would greatly extend an already lengthy article. In brief, however, we are convinced that population policy does matter, at least in some contexts. For example, in Kenya the adoption of a population policy by President Kenyatta's government in 1967 opened a tap for funds that increasingly gushed from donors, and recent work by Deborah Barrett and Amy Tsui (1997) showed that third world countries adopting a neo-Malthusian policy typically experienced an increase in financial aid. In the case of Kenya, donors were disappointed with the results, as the funds were not spent as they had expected. Some funds, however, were used to train clinic workers in family planning. Although Kenya's total fertility rate did not decline until nearly two decades after the funds started flowing, nonetheless there was a steady increase over that period in the proportion of women of reproductive age using birth control. Although it is possible to argue a counterfactual-that this would have happened anyway for other reasons-we find it difficult to believe that the chain of events leading from the policy to the funds and to the increased availability of services had no impact on levels of contraceptive use.

8 A more extended treatment of this period is available in Hodgson and Watkins (1995).

9 After suffrage had been gained, Alice Paul and the National Woman's Party sought to rally American women around a goal of ending all legal discrimination against women. Wishing to preserve solidarity by keeping feminism's focus narrow, Paul attempted to prevent discussion at the NWP's 1921 convention of issues she feared might divide 
women, among which she included race relations, disarmament, and birth control (Cott 1987: 68). Although the NWP did focus its efforts on passing an equal rights amendment, women never united behind this goal. The leadership of the NWP defined equality as embodied in laws that treat men and women in an identical fashion, and many women who had fought for laws that offered women special protection objected to this definition. By the end of the 1920s "feminism" had become a divisive term among American women (Cott 1987: 134-135).

10 Thompson did nothing to avoid controversy. Indeed, his early writings on the demography of Japan (1929b: 18-48, $113-$ 139; 1930: 225-226, 264-269, 359-366) were aimed at convincing Western policymakers of the demographic necessity of Japanese territorial expansion. During the $1930 \mathrm{~s}$ demographers even took upon themselves the task of refuting the demographic validity of Germany's Lebenstaum arguments for expansion into Eastern Europe (Kuczynski 1939).

11 Szreter (1993) argues that the "loss" of China to the "free world" after World War II made policymakers especially sensitive to the political hazards associated with disruptive social changes in Asia.

12 During the time when members of the Princeton group were formulating transition theory, no mention was made of Thompson's 1929 work. In 1950 Notestein noted that he had just come across this older work (1950: 335).

13 Sanger might have made more of an impact on the ability of women to control their fertility by counseling heiress Katherine McCormick to fund the birth control pill research of Gregory Pincus and John Rock than she did by her IPPF labors.

14 For an interesting treatment of the players at this conference see the account offered in the Population Bulletin, especially the section entitled "Communists, Roman Catholics and 'Neo-Malthusians' make strange bedfellows" (Cook 1955: 96-99).

15 John D. Rockefeller 3rd made the following plea in 1960 (quoted in Piotrow 1973: 49):
The problems of population are so great, so important, so ramified and so immediate that only government, supported and inspired by private initiative, can attack them on the scale required. It is for the citizens to convince their political leaders of the need for imaginative and courageous action-action which may sometimes mean political and economic opposition.

16 Berelson (1966: 665-666), for instance, noted this additional attribute of the KAP survey: "As an example, the KAP survey done in Turkey in 1963 was given wide attention and contributed to bringing about the recent change in national population policy. It may even be, contrary to the typical impression of national elites, that there is more political potential in this issue than political risk."

17 It is interesting to note that IPPF now has removed all hint of neo-Malthusianism from its mission statement. Its "Strategic Plan-Vision 2000" document (International Planned Parenthood Federation 1995) dedicates the organization to protecting individual reproductive rights: “To increase efforts to safeguard the individual's right to make free and informed choices in regard to reproductive and sexual health." There are even hints of anti-Malthusianism, with a promise to "contribute to and influence the debate on population/development and the environment in a manner that ensures the protection of the rights of the underprivileged to the benefits of development, and protects women's right to health against the pressures of imposed demographic goals."

18 The full memorandum was declassified on 3 July 1989 and is reprinted in Mumford (1994: 47-186); the 29-page Executive Summary of the memorandum had been declassified in 1982 and reprinted in Population and Development Review 8, no. 2. The 13 countries are Nigeria, Ethiopia, Egypt, Turkey, Indonesia, Brazil, Bangladesh, Thailand, India, Pakistan, Mexico, Colombia, and the Philippines.

19 One exception was a group of graduate students in demography who during the late 1960s and early 1970s published Concerned Demography and identified with third world interests (Greenhalgh 1996). 
20 Nor were they mentioned-if our memories serve-in our graduate training in demography in the 1970s.

21 Supreme Court decisions holding that an individual's constitutional right to privacy included the right to make birth control decisions with minimum state interference expanded legal access to contraception and abortion in the United States. Although Roe v. Wade provoked a movement to amend the Constitution and criminalize abortion, American feminists realized that emphasizing the fundamental nature of this right was its best defense.

22 For the debate on the role of family planning programs in fertility decline see Pritchett (1994) and Bongaarts (1994).

23 It is likely that considerable international pressure was exerted to achieve this. A dissertation by Deborah Barrett (1995) shows that most of the policies adopted were virtually identical in wording, and the timing of a country's adoption of a population policy was associated not only with domestic conditions (e.g., per capita GDP, population density) but also with the extent of its participation in (or isolation from) the international community.

24 The National Abortion Rights Action League has changed its name to the National Abortion and Reproductive Rights Action League.

25 In 197336.6 percent of American women were using the pill; by 1982 only 20.7 percent of women were using it (National Center for Health Statistics 1994: Table 16).

26 We are grateful to Vaughan (1996) for this insight.

27 The Global 2000 Report contended that the population of sub-Saharan Africa had already exceeded that region's carrying capacity, and that the entire world would reach that unenviable state within the next century. It predicted mortality rise unless rates of population growth were lowered soon.

28 Donaldson (1990: 132) and Moffett (1994: 286-287) describe the pressures within USAID to adopt new health rationales for its family planning program. Moffett contends:
By the end of the Reagan years, moreover, the expenditures that were being made were being justified on a substantially narrower basis. Since its inception, the population program within U.S. AID had been devoted primarily, if not exclusively, to demographic goals. ... Under pressure from the right, such cosmic justifications were jettisoned during the Reagan administration in favor of the narrower though still important goal of improving family welfare-in particular maternal and child health-through greater access to family planning.

It is unclear whether much change occurred in the actual implementation of AID-sponsored family planning programs.

29 Despite changes in their rate of growth, funds have continued to flow. There are no firm estimates of the annual expenditures on population programs, but a commonly used figure (Mauldin 1995) for recent years is $\$ 4.5$ to $\$ 5$ billion, $\$ 1$ billion of which comes from donors, including more than $\$ 350$ million from the US government.

30 It is found in Principle 8 (United Nations 1992), which states: “To achieve sustainable development and a higher quality of life for all people, States should reduce and eliminate unsustainable patterns of production and consumption and promote appropriate demographic policies."

31 Margaret Hempel of the Ford Foundation noted (1994): "I thought that the environmental groups were going to be the big bully on the block." Yet she found that "in the end, they have been the least of the problem."

32 We thank Amy Higer (1996) for permission to quote from the draft introduction to her dissertation-in-progress. Everyone we interviewed specifically credits the International Women's Health Coalition with a leading role in integrating women's reproductive health in the Cairo agenda.

33 For example, inside USAID as well as within agencies that cooperated with it, a loose network of reproductive health feminists (many in low-level but sensitive positions) had formed in order to pressure the agency to meet women's reproductive health needs. They set up a Reproductive Health Task Force, a Gender Working Group, an 
Adolescent Health Working Group, and an Abortion Working Group (Higer 1996 and personal communication).

34 Assessing the influence of Southern feminists is beyond the scope of this article, but an in-depth analysis of the interactions between Northern and Southern feminists is much needed. The relationship between such feminists in the international women's reproductive health movement is not easy to categorize. Southern feminists speak with authority about the hopes and fears of Southern women, the main population to be served by the movement, and their judgments are accorded great respect. Yet their participation in international meetings and conferences usually is heavily subsidized by certain foundations and Northern governments. Northern feminists actively lobby to secure this funding and often are in a position to influence the level and composition of Southern representation.

35 Dunlop had previously been the "population aide" to John D. Rockefeller 3rd, hired in 1973, and had influenced his "conversion" to a developmentalist position at Bucharest in 1974 (Harr and Johnson 1991: 423-442); she thus had a history of both cooperation with and opposition to the neoMalthusian movement. Adrienne Germain had previously worked for the Ford Foundation, and at the time she first joined the International Women's Health Coalition she was a visiting senior associate at the Population Council. Both were well connected in foundation circles, which may have facilitated IWHC's ability to raise funds from foundations.

36 A 1983 IWHC brochure described its mission as dealing with problems of women's health and rapid population growth. There is no use of the term "reproductive rights," although women are seen as having the right to choose whether and when to have children.

37 Also included were child survival and primary health care professionals, women's health advocates, feminists "concerned with 'women in development," and general proponents of "social justice and human rights who recognize that women cannot exercise their basic rights fully unless they have ef- fective access to comprehensive reproductive health care."

38 Many of these issues were well developed in a series of papers by Judith Bruce and her colleagues (see, for example, Bruce 1987, 1990).

39 Some notable population-oriented representatives declined the invitation: the Centre for Development and Population Activities (CEDPA), Population Action International (PAI), and Steven Sinding, Director of Population Sciences at the Rockefeller Foundation.

40 WEDO's leaders shared these suspicions of neo-Malthusian efforts. For instance, Susan Davis contended (1994) that third world poverty "fundamentally is a development problem and the populationists' way of looking at the world is such a narrow way of looking at the world that it doesn't understand the root causes of the problems... it really does not address inequity and racism."

41 According to Nahid Toubia, a participant at the Rio meeting, only one numerical vote on a resolution was taken, and in that vote the majority declared that a feminist agenda should not include a population policy since any population policy entails controlling women's bodies.

42 Six weeks earlier, however, Speidel had pointed out that "they [advocates of a feminist population policy] never face the issue of what to do when resources are scarce, and they are" (quoted in Chira 1994: Al2).

43 "Common ground" was the phrase for this agenda that appeared a number of years before Cairo. For example, "Creating common ground," published by the World Health Organization, is the report of "a meeting between women's health advocates and scientists" organized by WHO and IWHC in Geneva in 1991. Hartmann, a long-time critic of population control activities (1987, 1995), claimed that this "common ground" consensus was "manufactured by a few powerful funders," specifically mentioning the Pew Charitable Trusts, Wirth's office at the State Department, UNFPA, and Ted Turner (quoted in Greene 1994: 7-8). The Ford and MacArthur Foundations also provided funding. 
44 Pope John Paul II met with President Clinton in June 1994 to discuss his concerns about the Cairo conference, and a week before the start of the conference Vatican spokesman Joaquin Navarro-Valls personally assailed Vice President Gore, the head of the US delegation, for his alleged support of "abortion on demand." The preeminent position that struggles over abortion wording assumed in Program of Action negotiations itself reflects a conference driven more by Northern than Southern concerns. In our view abortion is more a symbolic issue for Northern feminists, especially American feminists, than it is for Southern feminists.

45 For the hallway discussions, we rely on informal reports from a number of people who were there. For the press analysis, we rely on Neidell's (forthcoming) analysis of articles on the Cairo conference published in the New York Times between 18 August 1994 and 14 September 1994, which showed that coverage emphasized the issues of women's empowerment and abortion.

46 Petchesky (1995) contends that after ratification of the Program of Action at Cairo, feminists must also worry about ignoring issues of class, race, and justice. Although the document "enshrines an almost-feminist vision of reproductive rights and gender equality in place of the old population control discourse," it also "retains a mainstream model of development under which that vision cannot possibly be realized" (1995: 152).
47 Even emphasis on women's autonomy is suspect to some (Bandarage 1994: 12): "As fertility control is presented increasingly as the means for women's empowerment, feminist criticisms of coercion and experimentation within family planning programs get softened; the resurgence of eugenics associated with the growth of new reproductive technologies gets overlooked; and the social structural roots of women's subordination and the global crisis tend to be forgotten."

48 Paragraph 4.15 of the Program of Action states that "'son preference' . . is often compounded by the increasing use of technologies to determine foetal sex, resulting in abortion of female foetuses." Daniel Goodkind $(1996 a, 1996 \mathrm{~b})$ treats a number of issues surrounding sex-selective abortion that did not get addressed at the Cairo conference.

49 One donor has speculated in confidence that the US Congress might possibly be interested in the reproductive health of women in Anacostia, a poor and largely black section of Washington, D.C., but is unlikely ever to be interested in the reproductive health of women in Bangladesh.

50 Camp (1994: 124-126) questions whether this is the case. She contends that US antiabortion forces are also opposed to "all methods of birth control" and actively seek to "tar family planning with the proabortion brush."

\section{References}

Abzug, Bella. 1994. "Statement by Bella Abzug, co-chair, Women's Environment and Development Organization," at the Preparatory Committee Meeting of the International Conference on Population and Development, United Nations, New York, 4 April 1994. Electronic publication by Earth Negotiations Bulletin (enb@igc.apc.org), published by International Institute for Sustainable Development (iisd@web.apc.org).

Akhter, Farida. 1992. "The eugenic and racist premise of reproductive rights and population control," Issues in Reproductive and Genetic Engineering 5, no. 1: 1-8.

Bachrach, Peter and Elihu Bergman. 1973. Power and Choice: The Formation of American Population Policy. Lexington, MA: D.C. Heath.

Bambara, Toni Cade. 1970. "The pill: Genocide or liberation?" in Toni Cade Bambara (ed.). The Black Woman, pp. 162-169. New York: New American Library.

Bandarage, Asoka. 1994. "A new and improved population control policy?" Political Environments 1: 10-15. 
Barrett, Deborah. 1995. "Reproducing persons as a global concern: The making of an institution," Ph.D. dissertation, Stanford University.

Barrett, Deborah and Amy Ong Tsui. 1997. "A consequence of national population policies: The financial response of the international donor community," Working Paper, Carolina Population Center, Chapel Hill, North Carolina.

Bearman, Peter S. and Kevin D. Everett. 1993. "The structure of social protest, 1961-1983," Social Networks 15, no. 2: 171-200.

Berelson, Bernard. 1966. "KAP studies on fertility," in Bernard Berelson et al. (eds.), Family Planning and Population Programs, pp. 655-668. Chicago: University of Chicago Press.

- 1969. "Beyond family planning," Science 163, no. 3867 (7 February): 533-543.

Berer, Marge. 1991. "More than just saying 'no': What would a feminist population policy be like?" Conscience 12, no. 5 (September/October): 1-5.

Boland, Reed, Sudhakar Rao, and George Zeidenstein. 1994. "Honoring human rights in population policies: From declaration to action," in Sen, Germain, and Chen (1994): 89-105.

Bongaarts, John. 1990. "The measurement of wanted fertility," Population and Development Review 16, no. 3 (September): 487-506.

- 1991. "The KAP-gap and the unmet need for contraception," Population and Development Review 17, no. 2 (June): 293-313.

- 1994. "Population policy options in the developing world," Science 263, no. 5148 (11 February): 771-776.

Bram, Susan. 1978. "Women and children first or how pop planning fucked over mom," Heresies 6: 65, 67, 69, 71, 73.

Bruce, Judith. 1987. "Users' perspectives on contraceptive technology and delivery systems: Highlighting some feminist issues," Technology in Society 9, no. 3/4: 359-383.

- 1990. "Fundamental elements of the quality of care: A simple framework," Studies in Family Planning 21, no. 2 (March/April): 61-91.

Buechler, Steven M. 1990. Women's Movements in the United States: Woman Suffrage, Equal Rights, and Beyond. New Brunswick: Rutgers University Press.

Buhle, Mari Jo. 1983. Women and American Socialism, 1870-1920. Urbana: University of Mllinois Press.

Caldwell, John C. and Pat Caldwell. 1986. Limiting Population Growth and the Ford Foundation Contribution. Dover, NH: Frances Pinter Publishers.

Camp, Sharon L. 1993. "Population: The critical decade," Foreign Policy 90 (Spring): 126-144. . 1994. "The politics of U.S. population assistance," in Mazur (1994): 122-134.

Campbell, Martha Madison. 1993. "Schools of thought: Negotiation analysis applied to interest groups active in international population policy formulation," paper presented at the Annual Meeting of the Population Association of America, 1-3 April, Cincinnati.

Chesler, Ellen. 1992. Woman of Valor: Margaret Sanger and the Birth Control Movement in America. New York: Simon and Schuster.

Chinese Government. 1996. "Chinese government White Paper on family planning," reprinted in Population and Development Review 22, no. 2 (June): 385-390.

Chira, Susan. 1994. "Women campaign for new plan to curb the world's population," New York Times, 13 April: Al, A12.

Clark, Adele and Alice Wolfson. 1984. "Socialist-feminism and reproductive rights: Movement work and its contradictions," Socialist Review 14, no. 6 (Nov./Dec.): 110-120.

Clarke, R. F. 1896. “Neo-Malthusianism," North American Review 163 (September): 345-361.

Cleland, John. 1996. "ICPD and the feminization of population and development issues," Health Transition Review 6, no. 1 (April): 109-112.

Coale, Ansley J. and Edgar M. Hoover. 1958. Population Growth and Economic Development in Low-Income Countries. Princeton: Princeton University Press.

Cohen, Susan A. 1993. "The road from Rio to Cairo: Toward a common agenda," International Family Planning Perspectives 19, no. 2 (June): 61-71. 
Commission on Population Growth and the American Future. 1972. Population and the American Future. New York: New American Library.

Cook, Robert C. 1955. "Population in the United Nations," Population Bulletin 1 1, no. 7 (November): 93-105.

Cott, Nancy F. 1987. The Grounding of Modern Feminism. New Haven: Yale University Press.

Crane, Barbara B. 1993. "International population institutions: Adaptation to a changing world order," in Peter M. Haas, Robert O. Keohane, and Marc A. Levy (eds.), Institutions for the Earth: Sources of Effective International Environmental Protection, pp. 351-393. Cambridge: MIT Press.

Dalton, Russell J. and Manfred Kuechler (eds.). 1990. Challenging the Political Order: New Social and Political Movements in Western Democracies. New York: Oxford University Press.

Davis, Kingsley. 1967. "Population policy: Will current programs succeed?" Science 158, no. 3802 ( 10 November): $730-739$.

Davis, Susan. 1994. Personal interview with Susan Watkins and Dennis Hodgson, 24 May.

Demeny, Paul. 1994. “Population and development," Distinguished Lecture Series on Population and Development. Liège: International Union for the Scientific Study of Population.

Dixon-Mueller, Ruth. 1987. “U.S. international population policy and 'The Woman Question," Journal of International Law and Politics 20, no. 1 (Fall): 143-167.

- 1993. Population Policy and Women's Rights: Transforming Reproductive Choice. Westport, CT: Praeger.

Donaldson, Peter J. 1990. Nature Against Us: The United States and the World Population Crisis, 1965-1980. Chapel Hill: University of North Carolina Press.

Dublin, Louis I. 1926. "The fallacious propaganda for birth control," Atlantic Monthly 137. no. 2 (February): 186-194.

- 1932. "Birth selection vs. birth control: Eminent sociologists, scientists and publicists discuss Dr. Henry Fairchild Osborn's address at the Third International Eugenics Congress," Birth Control Review 16, no. 8 (October): 233.

Dublin, Louis I. and Alfred Lotka. 1925. "On the true rate of natural increase," Journal of the American Statistical Association 20, no. 150 (September): 305-339.

Ehrenreich, Barbara, Mark Dowie, and Stephen Minkin. 1979. "The charge: Gynocide; The accused: The U.S. Government," Mother Jones 4, no. 11 (November): 26-37.

Ehrlich, Paul R. 1968. The Population Bomb. New York: Ballantine Books.

Ehrlich, Paul R. and Anne H. Ehrlich. 1972. Population, Resources, Environment: Issues in Human Ecology, Second Edition. San Francisco: W. H. Freeman and Company.

Eisenhower, Dwight D. 1963. "Let's be honest with ourselves," Saturday Evening Post (26 October): 27.

Enke, Stephen. 1963. Economics for Development. Englewood Cliffs: Prentice-Hall.

Fairchild, Henry Pratt. 1940. Speech at the 1940 Annual Meeting of the Birth Control Federation. Found in Planned Parenthood Federation of America Papers, Sophia Smith Collection, Smith College Library. Quoted in Gordon (1990): 285.

Finkle, Jason L. and Barbara B. Crane. 1975. "The politics of Bucharest: Population, development, and the new international economic order," Population and Development Review 1, no. 1 (September): 87-114.

1985. "Ideology and politics at Mexico City: The United States at the 1984 International Conference on Population," Population and Development Review 11, no. 1 (March): 1-28.

Freedman, Lynn P. and Stephen L. Isaacs. 1993. "Human rights and reproductive choice," Studies in Family Planning 24, no. 1 (January/February): 18-30.

Germain, Adrienne. 1987. "Reproductive health and dignity: Choices by Third World women," background paper prepared for the International Conference on Better Health for Women and Children through Family Planning, held in Nairobi, Kenya, 5-9 October. New York: Population Council.

. 1994. Personal interview with Susan Watkins and Dennis Hodgson, 24 May. 
Goffman, Erving. 1974. Frame Analysis: An Essay on the Organization of Experience. Cambridge: Harvard University Press.

Goldman, Emma. 1916. "The social aspects of birth control," Mother Earth 11, no. 12 (April): 468-475.

Goodkind, Daniel. 1996a. "Sex-selective abortion, inequality, and reproductive rights: Questions left unasked and unanswered at Cairo," unpublished paper, Population Studies Center, University of Michigan.

- 1996b. "On substituting sex preference strategies in East Asia: Does prenatal sex selection reduce postnatal discrimination?" Population and Development Review 22, no. 1 (March): 111-125.

Gordon, Linda. 1974. "The politics of population: Birth control and the eugenics movement," Radical America 8, no. 4: 61-97.

- 1976. Woman's Body, Woman's Right. New York: Grossman Publishers.

- 1990. Woman's Body, Woman's Right, Revised Edition. New York: Penguin Books.

Gore, Al. 1992. Earth in the Balance: Ecology and the Human Spirit. Boston: Houghton Mifflin.

Grant, Nicole. 1992. The Selling of Contraception: The Dalkon Shield Case. Columbus: Ohio State University Press.

Green, Marshall. 1993. "The evolution of US international population policy," Population and Development Review 19, no. 2 (June): 303-321.

Greene, Stephen G. 1994. "Philanthropy's population explosion," The Chronicle of Philanthropy (31 May): 6-8.

Greenhalgh, Susan. 1996. "The social construction of population science: An intellectual, institutional, and political history of twentieth-century demography." Comparative Studies in Society and History 38, no. 1 (January): 26-66.

Greer, Germaine. 1984. Sex and Destiny: The Politics of Human Fertility. New York: Harper and Row.

Harkavy, Oscar. 1995. Curbing Population Growth: An Insider's Perspective on the Population Movement. New York: Plenum Press.

Harr, John Ensor and Peter J. Johnson. 1991. The Rockefeller Conscience: An American Family in Public and in Private. New York: Charles Scribner's Sons.

Hartmann, Betsy. 1987. Reproductive Rights and Wrongs: The Global Politics of Population Control and Contraceptive Choice. New York: Harper and Row.

- 1990. "Population policies and programs: A feminist assessment," Radical America 24, no. 2 (1 April): 45-51.

- 1995. Reproductive Rights and Wrongs: The Global Politics of Population Control and Contraceptive Choice, Revised Edition. Boston: South End Press.

Hartmann, Betsy and Hilary Standing. 1985. Food, Saris and Sterilization: Population Control in Bangladesh. London: Bangladesh International Action Group.

Hempel, Margaret. 1994. Personal interview with Susan Watkins and Dennis Hodgson, 24 May.

Higer, Amy P. J. 1996. “Transnational movements and world politics: The international women's health movement and population policy," dissertation-in-progress, Department of Politics, Brandeis University.

Hilgartner, Steven and Charles Bosk. 1988. "The rise and fall of social problems: A public arenas model," American Journal of Sociology 94, no. 1 (January): 53-78.

Hodgson, Dennis. 1983. "Demography as social science and policy science," Population and Development Review 9, no. 1 (March): 1-34.

Hodgson, Dennis and Susan Cotts Watkins. 1995. "Population controllers and feminists: Strange bedfellows at Cairo?" presented at the session on "The Role of Experts/Intellectuals in State Policy," 1995 Social Science History Association Meeting, 17 November, Chicago.

ICPD 94. 1994. "State Department leader describes new U.S. commitment to women's rights," ICPD 94 (Newsletter of the International Conference on Population and Development). No. 14 (April). Cairo: United Nations, Electronic Publication. 
International Planned Parenthood Federation. 1995. "Strategic Plan-Vision 2000." Electronic document found at the IPPF WWW site, http://www.oneworld.org/ippf/ strategic_2000.html

International Women's Health Coalition. 1993. Women's Voices '94: Women's Declaration on Population Policies. New York: IWHC. Reprinted in Population and Development Review 19. no. 3 (September 1993): 637-640 and in Sen, Germain, and Chen (1994): 31-34.

1994. "The Rio statement of reproductive health and justice, international women's health conference for Cairo 1994." New York: IWHC.

Johnson, Stanley P. 1987. World Population and the United Nations: Challenge and Response. New York: Cambridge University Press.

Kardam, Nüket. 1991. Bringing Women In: Women's Issues in International Development Programs. Boulder: Lynne Rienner Publishers.

Kelley, Ailen C. and Robert M. Schmidt. 1994. "Population and income change: Recent evidence," World Bank Discussion Paper, No. 249. Washington, D.C.: World Bank.

Kuczynski, Robert R. 1939. "Living Space" and Population Problems. Oxford: Clarendon Press.

Lande, Robert E. I 995. "New era for injectables," Population Reports, Series K, No. 5. Baltimore: Johns Hopkins School of Public Health, Population Information Program.

Malawi Government. 1995. Malawi Population and Development Policy. Zomba: Government Press for the Department of Economic Planning and Development.

Mass, Bonnie. 1972. The Political Economy of Population Control in Latin America. Montreal: Editions Latin America.

- 1974. "An historical sketch of the American population control movement," International Journal of Health Services 4, no. 4: 651-676.

- 1976. Population Target: The Political Economy of Population Control in Latin America. Toronto: Women's Educational Press.

Mauldin, W. Parker. 1995. Personal interview with Susan Watkins.

Mazur, Laurie Ann (ed.). 1994. Beyond the Numbers: A Reader on Population, Consumption, and the Environment. Washington, D.C.: Island Press.

McAdam, Doug. 1982. Political Process and the Development of Black Insurgency, 1930-1970. Chicago: University of Chicago Press.

McCann, Carole Ruth. 1994. Birth Control Politics in the United States, 1916-1945. Ithaca: Cornell University Press.

McCarthy, John D. and Mayer N. Zald. 1977. "Resource mobilization and social movements," American Journal of Sociology 82 (May): 1212-1242.

McGrory, Elizabeth. 1994. Personal interview with Susan Watkins and Dennis Hodgson, 24 May.

McHugh, James T. 1984. "Population strategies and the United States," in Franco Biffi (ed.), Demographic Policies from a Christian Viewpoint: Proceedings of the Symposium, Rio de Janeiro, 27-30 September 1982, pp. 409-425. Rome: International Federation of Catholic Universities.

McIntosh, C. Alison and Jason L. Finkle. 1995. “The Cairo conference on population and development: A new paradigm?" Population and Development Review 21, no. 2 (June): 223-260.

McNicoll, Geoffrey. 1994. Review of Laurie Ann Mazur (ed.), Beyond the Numbers: A Reader on Population, Consumption, and the Environment, in Population and Development Review 20, no. 3 (September): 656-661.

McPherson, Peter. 1985. "International family planning: The reasons for the program," speech delivered to the American Enterprise Institute, Washington, D.C., 25 November.

Meyer, David S. and Nancy Whittier. 1994. "Social movement spillover," Social Problems 41, no. 2 (May): 277-298.

Mintz, Morton. 1985. At Any Cost: Corporate Greed, Women, and the Dalkon Shield. New York: Pantheon.

Moffett, George D. 1994. Critical Masses: The Global Population Challenge. New York: Viking. 
Moore, Hugh. 1956. The Population Bomb. New York: Hugh Moore Fund.

Morris, Aldon D. and Carol McClurg Mueller (eds). 1992. Frontiers in Social Movement Theory. New Haven: Yale University Press.

Mueller, Carol McClurg. 1992. "Building social movement theory," in Morris and Mueller (1992): 3-25.

Mumford, Stephen D. 1994. The Life and Death of NSSM 200: How the Destruction of Political Will Doomed a U.S. Population Policy. Research Triangle Park, NC: Center for Research on Population and Security.

National Center for Health Statistics. 1994. Health, United States, 1993. Hyattsville, MD: NCHS.

National Research Council. 1986. Population Growth and Economic Development: Policy Questions. Washington, D.C.: National Academy Press.

Neidell, Shara G. Forthcoming. "Women's empowerment as a public problem," Population Research and Policy Review.

Notestein, Frank W. 1950. "The population of the world in the year 2000," American Statistical Association Journal 45 (September): 335-345.

- 1982. "Demography in the United States: A partial account of the development of the field," Population and Development Review 8, no. 4 (December): 651-687.

Osborn, Frederick Henry. 1960. This Crowded World. New York: Public Affairs Committee.

Petchesky, Rosalind Pollack. 1995. "From population control to reproductive rights: Feminist fault lines," Reproductive Health Matters, No. 6 (November): 152-161.

Piotrow, Phyllis Tilson. 1973. World Population Crisis: The United States Response. New York: Praeger.

Piven, Frances Fox and Richard A. Cloward. 1977. Poor People's Movements: Why They Succeed, How They Fail. New York: Pantheon.

Popenoe, Paul. 1917. "Birth control and eugenics," Birth Control Review 1, no. 3 (April-May): 6.

Population Council. 1978. The Population Council: A Chronicle of the First Twenty-Five Years, 1952-1977. New York: Population Council.

Potts, Malcolm. 1995. "Cairo's skewed consensus," Population Today 23, no. 11 (November): 4-5.

- 1996. "USA aborts international family planning," The Lancet 347, no. 9001 (2 March): 556.

Preston, Lewis. 1994. "A call to action: Slowing population growth and accelerating sustainable development," an address to the International Conference on Population and Development, by the president of the World Bank Group, Cairo, 6 September. Electronic publication by United Nations Development Programme: gopher://gopher. undp.org:70/00/ungophers/popin/icpd/conference/una/940913120427

Preston, Samuel H. 1986. "Changing values and falling birth rates," Population and Development Review 12 (Supp): 176-195.

Pritchett, Lant H. 1994. "Desired fertility and the impact of population policies," Population and Development Review 20, no. 1 (March): 1-55.

Rockefeller, John D. 3rd. 1974. "Population growth: The role of the developed world," Lecture Series on Population. Liège: IUSSP. Reprinted in Population and Development Review 4 , no. 3 (September 1978): 509-516.

Roosevelt, Theodore. 1907. "A letter from President Roosevelt on race suicide," American Monthly Review of Reviews 35, no. 5 (May): 550-551.

Ross, Edward Alsworth. 1920. "The growth of population," Birth Control Review 4, no. 3: 57, 17-18.

1927. Standing Room Only? New York: The Century Company.

Royal Society of London and the US National Academy of Sciences. 1992. Population Growth, Resource Consumption, and a Sustainable World. Reprinted in Population and Development Review 18, no. 2 (June): 375-378.

Sadik, Nafis. 1996. "Statement by Dr. Nafis Sadik, Executive Director of the United Nations Population Fund," to the Conference on Women, Poverty and Population, Washing- 
ton, D.C., 9 February. Electronic publication by UNFPA: gopher://gopher.undp.org:70/ 00/ungophers/popin/unfpa/speeches/1996/cedpa.asc.

Sanger, Margaret. 1919. "Birth control and racial betterment," Birth Control Review 3, no. 2: 11-12.

1922. The New Motherhood. London: Jonathan Cape.

1925. "The need for birth control in America," in Adolf Meyer (ed.), Birth Control: Facts and Responsibilities, pp. 11-49. Baltimore: Williams and Wilkins.

- 1926. "The function of sterilization," Birth Control Review 10, no. 10 (October): 299.

Sen, Gita, Adrienne Germain, and Lincoln C. Chen (eds.). 1994. Population Policies Reconsidered: Health, Empowerment, and Rights. Boston: Harvard University Press.

Shapiro, Thomas M. 1985. Population Control Politics: Women, Sterilization, and Reproductive Choice. Philadelphia: Temple University Press.

Simon, Julian L. 1977. The Economics of Population Growth. Princeton: Princeton University Press.

Sinding, Steven W. 1993. "Getting to replacement: Bridging the gap between individual rights and demographic goals," Demography India (Delhi) 22, no. 1 (January-June): 1-10.

- 1994. "Population issues and Africa," testimony given 4 August to the House Foreign Affairs Committee. Washington, D.C.: Federal Document Clearing House, Congressional Testimony.

Sinding, Steven W., John Ross, and Allan Rosenfield. 1994. "Seeking common ground: Unmet needs and demographic goals," in Mazur (1994): 158-170.

Snow, David A., E. Burke Rochford, Jr., Steven K. Worden, and Robert D. Benford. 1986. "Frame alignment processes, micromobilization, and movement participation," American Sociological Review 51, no. 4 (August): 464-481.

Snow, David A. and Robert D. Benford. 1992. "Master frames and cycles of protest," in Morris and Mueller (1992): 133-155.

Staggenborg, Suzanne. 1991. The Pro-Choice Movement: Organization and Activism in the Abortion Conflict. New York: Oxford University Press.

Stoddard, (Theodore) Lothrop. 1920. The Rising Tide of Color Against White World Supremacy. New York: C. Scribner's Sons.

Stycos, J. Mayone. 1962. "A critique of the traditional Planned Parenthood approach in underdeveloped areas," in Clyde Kiser and J. Kantner (eds.), Research in Family Planning, pp. 477-501. Princeton: Princeton University Press.

- 1967. "Preliminary report to H.E.W. on the status of demographic training in the United States," Population Index 33, no. 3: 360-361.

- 1968. "American goals and family planning," in Franklin T. Brayer (ed.), World Population and U.S. Government Policy and Programs, pp. 19-44. Washington, D.C: Georgetown University Press.

Symonds, Richard and Michael Carder. 1973. The United Nations and the Population Question, 1945-1970. New York: McGraw-Hill.

Szreter, Simon. 1993. "The idea of demographic transition and the study of fertility change: A critical intellectual history," Population and Development Review 19, no. 4 (December): 659-701.

Thompson, Warren. 1929a. "Population," American Journal of Sociology 34, no. 6 (May): 959975.

1929b. Danger Spots in World Population. New York: Alfred A. Knopf.

1930. Population Problems. New York: McGraw-Hill.

United Nations. 1974. "Report of the United Nations World Population Conference, 1974," Bucharest, 19-30 August. E.75.XIII.3. New York: United Nations.

1984. "Mexico City Dedaration on Population and Development" of the International Conference on Population, Mexico City. A/CONF.171/13. New York: United Nations.

- 1992. "Rio Declaration." Report of the United Nations Conference on Environment and Development, Rio de Janeiro, 3-14 June. E.93.I.8. New York: United Nations. 
1994. "Programme of Action" of the 1994 International Conference on Population and Development, Cairo, Egypt, 18 October. A/CONF.171/13. New York: United Nations.

Vaughan, Diane. 1996. The Challenger Launch Decision: Risky Technology, Culture, and Deviance at NASA. Chicago: University of Chicago Press.

Vogt, William. 1948. Road to Survival. New York: W. Sloane Associates.

Watkins, Susan Cotts. 1993. "If all we knew about women was what we read in Demography, what would we know?" Demography 30, no. 4 (November): 551-577.

Watkins, Susan Cotts, Naomi Rutenberg and David Wilkinson. Forthcoming. "Orderly theories and disorderly women," in G. W. Jones, R. M. Douglas, J. C. Caldwell, and R. M. D'Souza (eds.), The Continuing Demographic Transition. Oxford: Oxford University Press.

Weisbord, Robert G. 1975. Genocide? Birth Control in Black America. Westport: Greenwood Press.

Westoff, Charles F. 1988. "The potential demand for family planning: A new estimate of unmet need and estimates for five Latin American countries," International Family Planning Perspectives 14, no. 2 (June): 45-53.

. 1994. "What's the world's priority task? Finally, control population," New York Times Magazine (6 February): 30, 32. . 1995. "International population policy," Society (May/June): 11-15.

Westoff, Charles F. and James McCarthy. 1979. "Population attitudes and fertility," Family Planning Perspectives 11, no. 2: 93-96.

Wilmoth, John R. and Patrick Ball. 1992. "The population debate in American popular magazines, 1946-90," Population and Development Review 18, no. 4 (December): 631-668.

Woloch, Nancy. 1984. Women and the American Experience. New York: Alfred A. Knopf. 